Preliminary draft: 8/17/2006

Do not cite.

\title{
FINANCIAL ACCOUNTING AND CORPORATE BEHAVIOR
}

\author{
DAVID I. WALKER ${ }^{*}$
}

\begin{abstract}
The power of financial accounting to shape corporate behavior is underappreciated. Positive accounting theory teaches that even cosmetic changes in reported earnings can affect share value, not because market participants are unable to see through such changes to the underlying fundamentals, but because of implicit or explicit contracts that are based on reported earnings and transaction costs. However, agency theory suggests that accounting choices and corporate responses to accounting standard changes will not necessarily be those that maximize share value. For a number of reasons, including the fact that executive compensation often is tied to reported earnings, managerial preferences for high earnings generally will exceed shareholder preferences, leading to share value reducing tradeoffs between reported earnings and net cash flows. The empirical literature on the details of positive accounting theory is mixed, but the evidence firmly establishes the power of accounting to shape corporate behavior.

The power of accounting and the divergence of interests have many implications for courts and policy makers. For example, consideration of proposals to increase conformity between tax and financial accounting rules as a means of combating tax sheltering and/or artificial earnings inflation must take into account the incentive properties of accounting standards and recognize that narrowing the gap between tax and book income will have economic consequences, however the gap is narrowed. This Article considers this and other implications of the behavioral effects of accounting standards, including the possibility of setting accounting standards instrumentally as a means of regulating corporate behavior, an alternative to tax incentives, mandates, or direct subsidies.
\end{abstract}

* Associate Professor, Boston University School of Law. I have benefited from the helpful comments of Vic Fleischer, Keith Hylton, Calvin Johnson, Mike Meurer, Alex Raskolnikov, Lynn Stout and participants in workshops at Boston University School of Law, the Junior Tax Scholars' Workshop, the Canadian Law and Economics Association annual meeting, and the National Tax Association annual meeting. I thank Mark Gauthier for excellent research assistance. 


\section{TABLE OF CONTENTS}

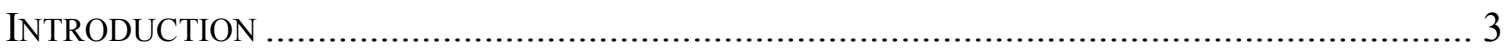

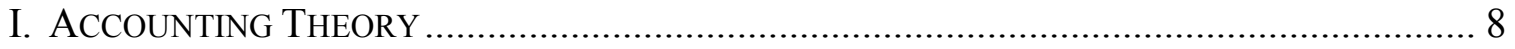

A. The Efficient Capital Markets Hypothesis and the Capital Assets Pricing Model .... 8

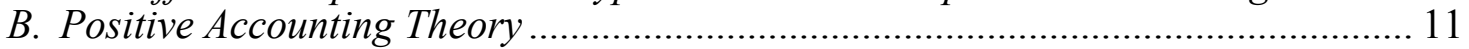

C. Shareholder and Manager Appetite for Earnings .................................................. 13

II. EMPirical Evidence on ACCOUnting, Share VAlue, AND Corporate Behavior 17

A. Stock Price Reaction to Changes in Mandatory Accounting Standards ................ 17

B. Corporate Response to Changes in Mandatory Accounting Standards .................. 19

C. Stock Option Expense Accounting..................................................................... 20

D. Voluntary Accounting Choice Evidence - Tax/Earnings Tradeoffs ........................ 23

III. Does Accounting Matter? Synthesis of THE Theory AND Evidence ................ 26

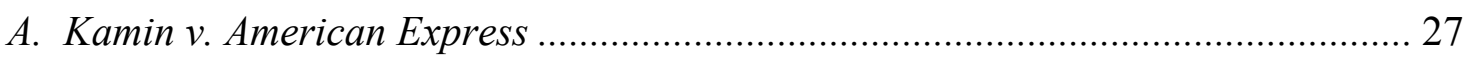

B. Managerial Opposition to Stock Option Expensing.............................................. 29

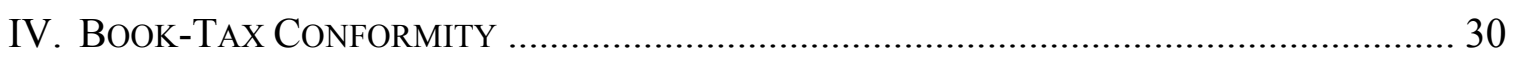

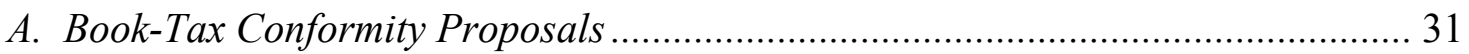

B. Issues and Concerns with Book-Tax Conformity Proposals .................................. 32

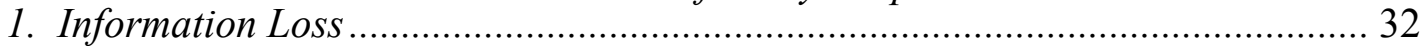

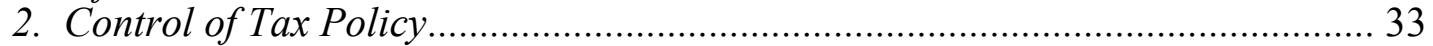

3. Instability Generally ............................................................................... 34

4. Politicization of the Financial Accounting Standard Setting Process................. 34

C. Book-Tax Conformity and Corporate Behavior .................................................. 35

1. Accounting and Operational Flexibility and the Book-Tax Tradeoff.................. 35

a. Flexibility in Managing Taxes and Earnings................................................ 36

b. The Book/Tax Tradeoff ............................................................................ 37

2. Discretion and Cross Company Consistency in Financial Reporting................... 38

3. Book-Tax Conformity and Economic Incentives................................................. 39

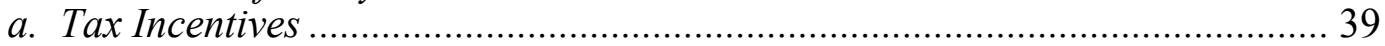

b. Accounting Incentives ......................................................................... 40

c. Economic Consequences of Eliminating Accounting Incentives ..................... 42

4. Economic Consequences and Flexible Book-Tax Conformity ............................ 43

D. Further Book-Tax Conformity Alternatives and Alternatives to Conformity ......... 44

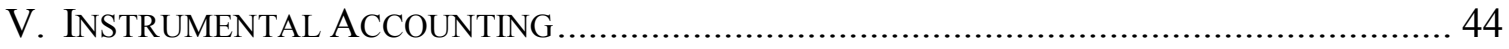

A. How Would Instrumental Accounting Work? …………................................... 45

B. Benefits of Instrumental Accounting ..................................................................... 46

C. The Costs of Instrumental Accounting ................................................................ 47

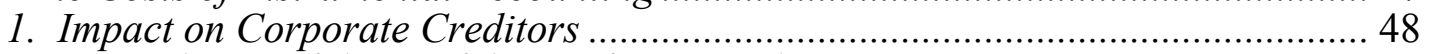

2. Degradation of the Usefulness of Financial Reports..............................................49

3. Lobbying, Regulatory Capture and the Quality of Accounting Incentives ........... 50

4. Institutionalization of the Importance of Reported Earnings .............................. 53

5. Conflict with International Convergence of Accounting Standards ..................... 53

6. Other Costs (and Benefits) of Instrumental Accounting .................................... 54

D. Thinking about Accounting Incentives in a Second Best World ............................ 55

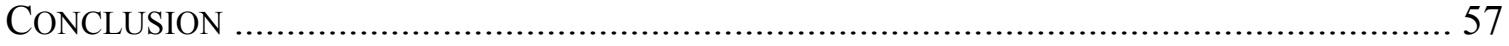




\section{INTRODUCTION}

Financial accounting standards and accounting decisions are vitally important to the managers of U.S. public companies. Nonetheless, the courts, policy makers, and legal scholars focusing on corporate law generally ignore accounting whenever they are able, treating the subject as a black box best left to accounting professionals, without recognizing the impact of accounting on managerial decision making and corporate behavior. This is unfortunate. Corporate financial accounting is too important to be left to the accountants. Courts and policy makers need to understand whether accounting standards and accounting decisions matter, and if so, how; whether managerial sensitivity to reported earnings reflects legitimate shareholder concerns, irrational behavior, or rational, but self-serving behavior; and finally whether accounting standards can serve a useful policy role in helping to shape managerial and corporate behavior. Consider the following examples:

In a case described in many corporate law texts and treatises, Kamin v. American Express, ${ }^{1}$ the company's directors voted to distribute to shareholders some depreciated securities rather than selling the securities and enjoying the benefit of a corporate tax loss. The plaintiffs' allegation, accepted by the court in considering the defendants' summary judgment motion, was that the directors had made a conscious decision to forego about $\$ 8$ million in tax savings in order to avoid a $\$ 26$ million dollar reduction in reported earnings, even though the \$26 million loss was suffered economically and was clearly reflected on the company's balance sheet. ${ }^{2}$ Because the American Express shareholders would be unable to use the tax loss, the primary beneficiary of this decision appeared to be the U.S. Treasury. The directors justified sacrificing after-tax cash flow for higher reported earnings arguing that a \$26 million "reduction of net income would have a serious effect on the market value of the publicly traded American Express stock."

The court held that the board's good faith decision was protected by the business judgment rule and dismissed the case. ${ }^{4}$ The court downplayed the plaintiffs' allegation that some of the directors were company managers whose compensation was based in part on reported earnings. Was the earnings/cash flow tradeoff in the Kamin case negligent? Was it even rational? Should the court have been more skeptical that the decision was in good faith and not self-serving behavior on the part of the inside directors?

Consider next the battle that has been waged over the last decade over the accounting treatment of compensatory stock options. The Financial Accounting

${ }^{1} 383$ N.Y.S.2d 807 (N.Y.Sup. 1976).

2 The case involved a block of stock that American Express had purchased in Donaldson, Lufken and Jenrette, Inc. that had declined in value from $\$ 30$ million to $\$ 4$ million. The loss on the stock was water under the bridge. The only question before the directors was whether the stock should be sold by American Express, providing a tax benefit to offset other income, but also a reduction in earnings; or distributed to shareholders as a dividend. In the latter case, the alternative selected by the directors, the tax benefit would be lost entirely - the shareholders would not be entitled to use it, but American Express's loss on the stock would be reflected only on its balance sheet, not on its income statement. See id. at 809810 .

${ }^{3} \mathrm{Id}$. at 811 .

${ }^{4}$ See id. at 812. 
Standards Board (FASB), the private body empowered by the SEC to set accounting standards, formally proposed in 1993 that stock option expense be recorded and subtracted from reported earnings similar to all other compensation expense. ${ }^{5}$ The corporate lobby managed to defer mandatory expensing for twelve years until FASB finally forced through a rule in $2004 .^{6}$

The effect of mandatory option expensing will be to reduce reported earnings for companies that use options. Corporate interests opposing the new standard have argued that expensing will reduce share values and drastically reduce or preclude the use of options as a compensation device. ${ }^{7}$ Some economists argue that the accounting treatment is irrelevant and that managerial resistance is irrational by traditional economic ways of thinking. ${ }^{8}$ Members of Congress actually have weighed in on this one - but on both sides of the question. ${ }^{9}$ Is managerial resistance to option expensing irrational or self-serving, or does it reflect legitimate concerns about the effect of expensing options on share value?

Next, increased consistency between financial and tax accounting has been proposed as a response both to tax sheltering and artificial earnings inflation. ${ }^{10}$ Differences between financial (or book) accounting and tax accounting allow firms to exploit tax shelters that decrease taxable income without affecting book income and artificially inflate reported earnings without incurring higher corporate taxes. Requiring firms to adopt the same accounting conventions for both purposes would force them to trade off taxes against reported earnings. Assuming some managerial discretion, commentators have generally assumed that the primary result of increased book-tax conformity would be reduced reported earnings, since managers would act to minimize taxes and maximize after tax cash flows. ${ }^{11}$ Does this view properly reflect the importance of reported earnings to management, or would shareholders likely suffer as a

5 See Financial Accounting Standards Board, Exposure Draft: Accounting for Stock-Based Compensation (1993).

${ }^{6}$ See Financial Accounting Standards Board, Statement of Financial Accounting Standards No. 123 (revised 2004) (Dec. 2004) (mandating "fair value" accounting for stock options effective beginning in 2005 and 2006).

${ }^{7}$ See, e.g., Wick Simmons, The Best Option, WALl ST. J., Jan. 31, 2003, at A10 ("[I]f companies are forced to treat options like salaries or manufacturing costs, many will decide they can't afford to continue this form of potential compensation.").

${ }^{8}$ See Kevin J. Murphy, Explaining Executive Compensation: Managerial Power Versus the Perceived Cost of Stock Options, 69 U. CHI. L. REV. 847, 860 (2002) (arguing that "[t]here is substantial evidence that managers respond to accounting concerns in ways that seem irrational to financial economists").

9 See Patricia M. Dechow et al, Economic Consequences of Accounting for Stock-Based Compensation, 34 J. ACCT. RES. 1, 3-4 (1997).

${ }^{10}$ See, e.g., George K. Yin, Getting Serious About Corporate Tax Shelters: Taking a Lesson from History, 54 S.M.U. L. REV. 209 (2001); Mihir A. Desai, The Degradation of Corporate Profits (working paper, June 2004).

11 See, e.g., Calvin H. Johnson, GAAP Tax, 83 TAX NoTES 425 (1999) (arguing that book-tax conformity would cause a significant drop in GAAP income); Yin, supra note 10, at 227 (noting that a tax based primarily on financial income could lead some companies to report lower earnings to reduce taxes); Michelle Hanlon \& Terry Shevlin, Book-Tax Conformity for Corporate Income: An Introduction to the Issues 28 (working paper, Oct. 2004) (noting that book-tax conformity could lead to a race to the bottom on effective tax rates). To be sure, none of these sources suggest that firms would completely ignore reported earnings, but the general tenor is that tax effects would likely dominate. 
result of increased book-tax conformity as managers forewent valid tax deductions in order to keep reported earnings high? More importantly, what would be the broader economic consequences of eliminating the gaps between financial and tax accounting?

Finally, consider a hypothetical accounting standard change that has the effect of decreasing reported expenses (and thus increasing reported earnings) related to the purchase of a certain class of assets. Given managerial sensitivity to reported earnings as demonstrated in Kamin, the stock option expensing saga, and numerous studies recounted below, would such an accounting change serve as a valuable incentive device, perhaps as an alternative to tax incentives? This Article argues that the stock option accounting regime in place over the last decade has, in fact, acted as an accounting incentive and helps explain the widespread use of options. This was largely unintentional and probably not salutary, but the impact of accounting rules on compensation design suggests the potential for instrumental accounting.

Thoughtful consideration of the foregoing questions requires exploration of accounting theory and related empirical evidence. Accounting theory seeks to explain how accounting standards affect share prices and corporate behavior and how firms choose between permissible standards. One goal of this Article is to introduce the legal academic community to the dominant theory among accounting researchers today, which is known as positive accounting theory. ${ }^{12}$

In brief, positive accounting theory posits that accounting matters because of transaction costs. ${ }^{13}$ Absent transaction costs, accounting standards and practices would be irrelevant because the capital markets are able to "see through" various accounting presentations to the underlying value of securities as long as (1) there are no tax or other direct cash flow effects and (2) there is no material change in the information publicly available to investors. ${ }^{14}$ The markets cannot be fooled, for example, by a firm switching its method of financial depreciation. However, a change in accounting standards can affect a firm's cash flows if that change affects various explicit or implicit contracts that are tied to reported financial results. For example, most public companies issue debt that is protected by accounting-based covenants. In order to ensure sufficient assets to repay the debt, borrowers typically covenant, inter alia, to maintain a certain level of working capital and to limit the pool from which dividends may be paid to shareholder investment

12 Although legal academics generally are familiar with the efficient capital markets hypothesis and the capital asset pricing model, which form the basis of modern accounting theory, references in the legal literature to positive accounting theory are sparse. A terms and connectors search of the "JLR" database in Westlaw for "positive accounting theory" produces only nine hits.

13 See generally Ross L. WATts \& Jerold L. ZIMMERMAn, POSITIVE ACCOUnTING TheORY (1986); Ross L. Watts \& Jerold L. Zimmerman, Positive Accounting Theory: A Ten Year Perspective, 65 ACCT. REV. 131 (1990); see also infra Part I.B.

14 At one time, researchers concluded based on these theories that accounting standards and practices were essentially irrelevant. See, e.g., WATTS \& ZimMERMAN, supra note 13, at 72-73; Watts \& Zimmerman, supra note 13, at 133 (discussing accounting irrelevance theory); Robert W. Holthausen \& Richard W. Leftwich, The Economic Consequences of Accounting Choice, 5 J. ACCT. \& ECON. 77, 80 (1983) (discussing early tests finding no stock price reaction to changes in accounting techniques except for changes affecting taxes); see also infra Part I.B.

However, accounting standards seemed to matter in practice, and researchers noticed patterns in firms' choices between acceptable accounting standards that were surprisingly regular if accounting were irrelevant. A fuller theory was required, and positive accounting theory was the result. 
plus accumulated profits. ${ }^{15}$ Both the violation and renegotiation of debt covenants is costly. Thus, an accounting change that reduces reported earnings and increases the chance of covenant violation should reduce expected cash flows and adversely affect stock prices, particularly for firms that are highly leveraged. But positive accounting theory suggests that an earnings-reducing change may produce benefits as well. Sticky earnings-based compensation contracts would become less expensive for shareholders and the risk of high reported earnings resulting in costly political repercussions (think windfall profits taxes) would be reduced.

While positive accounting theory explains why shareholders might care about earnings, there are several reasons to believe that managers' appetite for high reported earnings will exceed that of the shareholders. Most importantly, to some extent managerial compensation is based directly or indirectly on reported earnings. In addition, managers may hold an honest but mistaken belief that reported earnings directly affect share value, a position known as the naïve investor view, or they may be socialized into placing inordinate importance on reported earnings as a result of the excessive attention that stock analysts place on these figures. As a result there often will be a conflict between shareholder and managerial preferences for earnings. Managerial agency theory, which focuses on the irreducible gap between shareholder preference and manager action in a world of imperfect information, suggests that shareholders will rarely win this contest. In my view, accounting academics have significantly underestimated the importance of managerial agency theory in their research. In a sense, the theoretical thrust of this Article is to more closely intertwine two existing, though heretofore largely independent, strands of research - positive accounting theory and agency theory.

The empirical evidence, which this Article reviews in some detail, supports this integrated view. ${ }^{16}$ The most consistent and robust result from the empirical literature on accounting and corporate behavior is confirmation of what any practitioner will tell you: accounting matters; it is not irrelevant. Or, more importantly, managers act as if accounting mattered. However, although some of the evidence is consistent with the detailed predictions of positive accounting theory, much of the evidence is equally consistent with a manager-driven or agency cost theory of accounting choice.

And that brings us back to the questions originally posed and the final goal of this Article, which is to consider the implications of a more nuanced understanding of accounting theory and corporate behavior. First, can managerial decisions like those in Kamin or managerial opposition to stock option expensing possibly be in shareholder interests? Possibly, but it's unlikely. Based on our current understanding of accounting theory, we cannot be certain that the American Express directors in Kamin were negligent or disloyal, or that managerial opposition to stock option accounting was largely selfserving, but it is reasonable to suspect that this is the case. ${ }^{17}$ In Kamin, for example, the decision to forego the corporate sale of securities and the tax benefit in that case in order to avoid a large earnings hit probably did provide some shareholder benefit. Assuming that American Express had debt outstanding, the earnings reduction would have pushed the company closer to technical default on their covenants. For this reason, and not because the stock market could not see through the transparent ruse of distributing the

\footnotetext{
${ }^{15}$ See WATTS \& ZimMERMAN, supra note 13 , at 211.

${ }^{16}$ See infra Part II.

${ }^{17}$ See infra Part III.
} 
devalued securities, the market price of American Express would have been negatively affected. It is almost inconceivable, however, that the adverse stock price effect would have approached the $\$ 8$ million tax benefit foregone or that the covenants could not have been renegotiated for less than $\$ 8$ million. More importantly, the analysis developed herein identifies the questions that shareholders and judges should ask in attempting to determine whether managers' accounting choices are driven by share value concerns or are self serving.

Second, positive accounting theory suggests that firms would not adopt a strategy of ignoring reported earnings and minimizing taxes in order to maximize share value in a world of increased book-tax conformity. However, this Article argues that managers would go even further in sacrificing tax benefits for higher reported earnings, in all likelihood foregoing legitimate tax deductions and impairing share value. ${ }^{18}$ In addition, we should think of financial accounting standards as creating incentives just like the tax rules. Thus, differences between the two sets of rules, such as depreciation rules that allow firms acquiring capital assets to report higher earnings to investors than to the tax authorities, can be thought of as tax incentives, accounting incentives, or both; and increased book-tax conformity, whether achieved by conforming tax with book, book with tax, or something in between, could have adverse consequences for the economy.

Third, once we recognize that financial accounting standards have strong behavioral effects and economic consequences, the natural question to ask is whether this power should be harnessed and explicit accounting incentives embraced as a public policy tool, a supplement to the direct subsidies, mandates, and tax incentives currently used by Congress to shape corporate behavior. ${ }^{19}$

It is an interesting possibility. Unlike tax incentives and direct subsidies, purposeful adjustments made to accounting standards to influence behavior would have no direct impact on the public fisc. But there would be costs. First, purposeful deviation from economic accounting, the accounting treatment that most closely follows the economics of the transaction, would result in degradation of the information content of accounting statements and greater costs to the users of these statements. ${ }^{20} \mathrm{~A}$ second potential cost lies in the introduction of additional lobbying into the accounting standard setting process and the possibility of regulatory capture by the interest group with the most at stake - management. ${ }^{21}$ In many ways the costs and benefits of providing explicit accounting incentives and tax incentives are similar. The difference is that mixed purposes, congressional involvement, and the attendant lobbying and capture issues are unavoidable in the tax realm, or perhaps more importantly, are irretrievably entrenched. This is not the case for financial accounting, which is subject to much less political infighting today than is tax. Thus, although an omniscient, benevolent, and disinterested power could increase social welfare through judicious manipulation of accounting rules, we must recognize that Congress is not such a power. While remaining open to the possibility of instrumental accounting, this Article concludes for now that social welfare is probably maximized by minimizing consideration of non-accounting consequences in the standard setting process.

\footnotetext{
${ }^{18}$ See infra Part IV.

${ }^{19}$ See infra Part V.

${ }^{20}$ See infra Part V.C.1.

${ }^{21}$ See infra Part V.C.3.
} 
The organization of this Article follows that of the introduction: Part I lays out the theory of accounting from the efficient capital markets hypothesis to positive accounting theory, with additional consideration of managerial agency theory. Part II considers the empirical evidence related to the behavioral effects of accounting choice and accounting standards. Part III synthesizes the theory and evidence and evaluates the implications for cases like Kamin and managerial opposition to stock options expensing. Part IV considers the implications of the behavioral effects of accounting on the book-tax conformity debate, and Part $\mathrm{V}$ takes this analysis one step further, examining the potential for instrumental use of accounting standards.

\section{ACCOUNTING THEORY}

All public companies prepare audited financial statements that are relied upon by investors and others. The most important statements are the income statement, which provides a summary of the company's performance over the previous year or quarter, and the balance sheet, which provides a snapshot view of the overall financial position of the company as of the end of the period. The numbers that receive the greatest attention in the financial press are the net profits or earnings figures from the income statement, often portrayed as earnings per share of stock outstanding. The art of accounting, though, lies in the detail, in determining how various transactions - purchases, sales, leases, commitments to retirees, etc. - are to be accounted for. Accountants rely on a body of rules known as generally accepted accounting principles, or GAAP. As the name implies, many of these rules have not been mandated but have simply become accepted by the accounting profession over time. Ultimately, however, the SEC is responsible for maintaining the integrity of the securities markets and has delegated to the FASB the power to promulgate mandatory and permissive rules of accounting practice as needed. As a result, companies today face an array of mandatory rules as well as choices between generally accepted treatments in preparing their financial statements.

Accounting theory seeks to explain how accounting standards affect share prices and corporate behavior and how firms choose between permissible standards. Our analysis begins with an exploration of the well-known efficient capital markets hypothesis and the less-well-known (to legal academics, anyway) positive accounting theory. These theories suggest that accounting matters not because stock valuation is directly affected by accounting choices or standards but because contracts and regulatory costs depend explicitly or implicitly on reported earnings and these arrangements are sticky. Because of transaction costs, reported earnings can have an indirect effect on share prices. Nonetheless, this Part goes on to argue that corporate decision makers have additional incentives beyond share price maximization to prefer higher reported earnings. Ultimately, the relationship between financial accounting and corporate behavior depends on managerial agency costs as well as other transaction costs.

\section{A. The Efficient Capital Markets Hypothesis and the Capital Assets Pricing Model}

Accounting and finance researchers generally believe that a change in accounting standards or practices that increases or decreases reported earnings, but has no impact on cash flow, transaction costs, or on the information provided to the marketplace, should 
have no effect on stock prices. ${ }^{22}$ Securities markets should see through such cosmetic accounting adjustments to the underlying fundamentals that determine valuation. This view follows directly from the efficient capital markets hypothesis (ECMH) and the capital asset pricing model (CAPM). ${ }^{23}$

The CAPM simply assumes that the value of a company, and hence its stock price, is a function of the cash flows and rates of return that are expected over time. ${ }^{24}$ There are three versions of the ECMH. The weak form holds that securities prices reflect all information incorporated in past prices. The semi-strong form of the ECMH holds that securities prices reflect all published information. The strong form holds that prices reflect all discoverable information. ${ }^{25}$ If we limit our inquiry to changes in accounting standards and choices that involve only the presentation of published information, we need only accept the semi-strong version of the ECMH to conclude that accounting has no direct effect on stock valuation. ${ }^{26}$ The evidence suggests, and most economists believe, that markets are at least semi-strong efficient. ${ }^{27}$

Lynn Stout, Lawrence Cunningham, and others have argued that markets may not be as efficient as economists generally presume, ${ }^{28}$ but I do not think that these criticisms undermine the modest claim made above. Stout's critique is primarily directed at assertions of strong form market efficiency and an even stronger view called fundamental value efficiency. ${ }^{29}$ The latter is the theory that prices not only reflect all available

${ }^{22}$ See Thomas D. Fields et al, Empirical Research on Accounting Choice, 31 J. ACCT. \& ECON. 255, 279-81 (2001) (noting that research in the 1970s supported market efficiency, and that researchers in the 1980s and early 1990s assumed efficiency and looked for other explanations for why accounting would matter, i.e., positive accounting theory. They note that some evidence produced in the 1990s is inconsistent with efficient markets and investor rationality, but conclude that the evidence is insufficient to draw strong inferences.)

Some accounting decisions, such as the choice between LIFO and FIFO inventory accounting, affect a firm's tax burden and after-tax cash flow. These accounting decisions would be expected to have share price implications under this theory. See infra notes 151-153 and accompanying text.

${ }^{23}$ See e.g., WATTS \& ZIMMERMAN, supra note 13, at 72-73; Watts \& Zimmerman, supra note 13, at 131, 133 (discussing accounting irrelevance theory).

24 See WATTS \& ZIMMERMAN, supra note 13, at 72-73.

${ }^{25}$ See Richard A. Brealey \& SteWARt C. MYers, PrinCiPles of Corporate FinanCE 351 (7th ed. 2003).

26 For example, suppose firms $\mathrm{ABC}$ and $\mathrm{XYZ}$ are identical except for their accounting for an expense of 10c per share. ABC reports earnings of $\$ 1.00$ per share and discloses the 10c per share expense in the footnotes to its accounting statements. XYZ subtracts the expense in its income statement reporting earnings of 90c per share. Under the naïve investor view that runs counter to the semi-strong ECMH, XYZ would trade for less than $\mathrm{ABC}$. Suppose that the price to earnings ratio for firms in this industry with prospects and risks similar to $\mathrm{ABC}$ and $\mathrm{XYZ}$ is 20. Under the naïve investor view, $\mathrm{ABC}$ would trade at \$20 per share, while XYZ would trade for \$18 per share. Because the expense is fully disclosed in both cases, the semi-strong version of the ECMH predicts that these firms would have an identical share price. The market would treat each as earning 90c per share.

27 See BREALEY \& MYERS, supra note 25, at 351-53. Evidence that earnings and dividend announcements are almost fully incorporated into stock prices within five to ten minutes supports semistrong market efficiency. See id. at 353.

28 See Lynn A. Stout, The Mechanisms of Market Inefficiency: An Introduction to the New Finance, 28 J. CORP. L. 635 (2003); Lawrence A. Cunningham, Behavioral Finance and Investor Governance, 59 WASH. \& LEE L. REV. 767 (2002).

${ }^{29}$ See Stout, supra note 28, at 637, 639 (describing the most common definition of an efficient market as one that reflects all available information) and Part II, generally (critiquing the fundamental value efficiency view). 
information but also provide the best estimate of the fundamental value of the underlying asset. $^{30}$ Fundamental value efficiency is quite hard to square with market corrections, so these criticisms are well taken. But in considering the differential impact of competing accounting standards or of accounting choices, we are not concerned with fundamental equity values, only with the impact of accounting on stock prices relative to one another or from one period to another. With regard to these issues, Stout argues that the cost of arbitrage and of acquiring and processing information, particularly technical information, undermines the efficiency with which information is impounded into prices. $^{31}$

Although I agree with Stout's criticisms as applied to strong form market efficiency theory, and perhaps to some examples of semi-strong efficiency, I am skeptical of her argument that accounting practices affect stock prices because of informational inefficiency. As an example of an accounting practice that may affect prices if markets are informationally inefficient, Stout mentions the debate over the treatment of compensatory stock options. ${ }^{32}$ This debate centers on whether stock option expense should be deducted from reported earnings in the body of the financial statement, as the FASB will now require, ${ }^{33}$ or detailed in the footnotes to the accounting statement. It is important to recognize, however, that this "footnote" provides exactly the same information that will be provided in the body of company financial statements once the new rule takes effect. Formerly, companies that did not "expense" options were required to present pro forma income statements revealing the net income and earnings per share figures that would have resulted had options been expensed. ${ }^{34}$ Thus, while I agree with Stout that the cost of acquiring and processing information can limit market efficiency in some circumstances, it is inconceivable to me that an income statement found on page three of the financial statement is any more informative than the exact same statement found on page thirty.

Of course, the stock option expensing example is the toughest case for those arguing that accounting standards affect stock prices because of informational inefficiencies. Other changes to accounting standards could have greater impact on the information presented to investors. I think we can safely say, however, that a change in standard that has no material effect on the information available to investors should have no direct effect on stock prices.

Similarly, it is difficult to understand how the accounting issue presented in Kamin could have any direct effect on the stock price of American Express. Recall that the directors chose to distribute rather than sell depreciated securities the company was holding as an investment. ${ }^{35}$ Sale of the securities would have provided a potential $\$ 8$

${ }^{30}$ See id. at 640 .

31 See id. at 651-56 and studies cited therein. Stout also explores the effects of heterogeneous investor expectations and investor irrationality on efficient market claims, but these limitations on efficiency, if significant, pose less of a challenge to the semi-strong model. See id., Parts II and IV.

${ }^{32}$ See id. at 657, n. 100.

${ }^{33}$ See infra note 90 and accompanying text.

${ }^{34}$ See Statement of Financial Accounting Standards No. 123, supra note 6, para. 45. Returning to the example in note 26 supra, if the $10 \mathrm{c}$ per share expense related to compensatory stock options, the footnoting option would allow $\mathrm{ABC}$ to report earnings of $\$ 1.00$ per share in its income statement, but $\mathrm{ABC}$ would be required to report pro forma earnings of 90c per share in the footnotes to its financial statements.

${ }^{35}$ See Kamin, 383 N.Y.S.2d at 809. 
million tax benefit, but also would have reduced reported earnings by $\$ 26$ million. ${ }^{36}$ Perhaps if the directors had been able to hide the investment loss from analysts by distributing the securities, the impact on the price of American Express shares might have been dampened. American Express stockholders, however, appeared to have been well aware of the economic loss that had been suffered. The company had announced that the depreciated securities would be distributed in kind as a special dividend, and apparently the company had provided enough information for some of the shareholders to realize that this action would result in the company foregoing a sizeable tax benefit. Ultimately, the board held a special meeting to reconsider distribution versus sale. Can there be any doubt at this point that the economic loss suffered had been fully incorporated in the stock price of American Express and that the additional step of reducing corporate earnings by the amount of the loss would have provided no new information to the market?

There can be no real doubt. Nonetheless, Lawrence Cunningham argues that the American Express directors still may have outsmarted the market by distributing the securities, and that their action reflected healthy skepticism about market efficiency. ${ }^{37}$ The thrust of his and similar arguments is that investor cognitive biases, including loss aversion (the tendency to place greater importance on losses than gains), overconfidence (the belief that we are all better than average drivers, stock pickers, etc.), and availability (the tendency to place greater weight on more recent events) undermine the efficiency of the capital markets. ${ }^{38}$ However, Cunningham does not explain which cognitive bias would cause "market participants [to] focus on the income statement and earnings per share rather than on the balance sheet and owner's equity,"39 and it is not obvious which, if any, cognitive bias would be at work here. Perhaps some investors overconfidently rely on raw earnings numbers or rely excessively on reported earnings and discount footnotes and balance sheets because the former are more salient, but this sounds less like bias and more like laziness. More generally, while there is evidence that market participants suffer from cognitive biases, it is not clear that these biases affect market prices. $^{40}$

\section{B. Positive Accounting Theory}

A believer in the semi-strong view of the ECMH might be tempted to conclude from the foregoing discussion that accounting standards and accounting choices are irrelevant, and this irrelevancy view held sway in the academic community for many

${ }^{36}$ See id. at 809-10.

${ }^{37}$ See Cunningham, supra note 28 , at 823-24.

${ }^{38}$ See id. at 775 and 783. See also BREALEY \& MYERS, supra note 25, at 358-59. As Stout notes the behavioral finance field has experienced explosive growth. I cite Cunningham as one example since he has specifically referenced the Kamin case, but many others could be cited. See Stout, supra note 28 , at 660, n. 115-117.

${ }^{39}$ Cunningham, supra note 28, at 823-24.

${ }^{40}$ See BREALEY \& MYERS, supra note 25, at 358-360 (questioning behavioral finance explanations for market anomalies and noting, inter alia, that financial institutions employ behavioral finance experts to assist them in overcoming these biases). 
years. ${ }^{41}$ However, researchers investigating company choices among acceptable accounting alternatives found enough systematic variation to doubt the irrelevancy theory and seek alternative explanations. For example, firm size and leverage (the ratio of corporate debt to equity) both appear to be associated with accounting choice, a result at odds with an irrelevancy view of accounting. ${ }^{42}$ Findings such as these have led researchers to search for indirect effects of accounting on share value, a field known as positive accounting theory. ${ }^{43}$

The ECMH only says that the securities markets see through cosmetic accounting changes. This does not necessarily mean that reported earnings are irrelevant. Many corporate contracts are tied to reported earnings, including debt covenants and executive compensation agreements. ${ }^{44}$ Renegotiating these contracts to adjust for accounting changes can be costly, while failure to renegotiate in face of a purely accounting-driven change in earnings can be costly as well. ${ }^{45}$ In addition, if an accounting-driven increase in reported earnings is difficult to distinguish from an increase in profits arising from business fundamentals, the earnings bump could have political ramifications, such as increased exposure to tax hikes or reduced subsidies. ${ }^{46}$ Finally, mandatory accounting changes that reduce corporate freedom to select optimal accounting techniques could reduce the value of financial statements for private contracting. ${ }^{47}$ All of these indirect effects of reported earnings on share value are referred to in the positive accounting theory literature as contracting costs.

Transaction costs resulting from sticky contracts and political costs resulting from an apparent surge in profits affect a company's cash flows. Thus, this explanation is perfectly consistent with the ECMH and CAPM. In developing the accounting irrelevance theory it had been assumed that accounting standards and practices did not affect transaction costs. The advance made by positive accounting theorists has been to eliminate this simplifying assumption and begin to explain the relevance of accounting to share price. $^{48}$

Consider the impact of accounting on corporate debt covenants. These covenants are based on GAAP accounting, which means that they are tied to reported earnings, and

${ }^{41}$ See Holthausen \& Leftwich, supra note 14, at 80 (discussing early tests finding no stock price reaction to changes in accounting techniques except for changes affecting taxes); Watts \& Zimmerman, supra note 13 , at 133 .

${ }^{42}$ See Holthausen \& Leftwich, supra note 14, at 79.

${ }^{43}$ See Watts \& Zimmerman, supra note 13.

${ }^{44}$ See id. at 133. See also Holthausen \& Leftwich, supra note 14, at 84-88.

${ }^{45}$ See WATTS \& ZIMMERMAN, supra note 13 , at 215.

${ }^{46}$ See id. at $222-23$.

${ }^{47}$ See id. at 219; Daniel W. Collins et al, The Economic Determinants of the Market Reaction to Proposed Mandatory Accounting Changes in the Oil and Gas Industry: A Cross-Sectional Analysis, 3 J. ACCT. \& ECON. 37, 43 (1981). In addition, a change in accounting standard may affect the reliability of information provided to the markets. New standards that reduce reliability would have a negative effect on firm value by increasing contracting costs generally. See Hassan Espahbodi et al, Impact on Equity Prices of Pronouncements Related to Nonpension Postretirement Benefits, 14 J. ACCT. \& ECON. 323, 327 (1991).

${ }^{48}$ There is an obvious analogy between the evolution of positive accounting theory and positive finance theory. Miller and Modigliani demonstrated in 1961 that corporate financing decisions, such as dividend payout policies, are irrelevant in the absence of transaction costs. See M. H. Miller \& F. Modigliani, Dividend Policy, Growth and the Valuation of Shares, 34 J. Bus. 411 (1961). Subsequent researchers demonstrated that taxes, agency costs, and other imperfections in the market render corporate finance relevant. See BREALEY \& MYERS, supra note 25, ch 16. 
they usually are based on "rolling" GAAP, that is, GAAP in effect at the time of calculation. ${ }^{49}$ Renegotiation of debt covenants can be difficult and costly, particularly covenants associated with publicly held debt which generally require a two-thirds vote of the outstanding debt for amendment. ${ }^{50}$ Violation of debt covenants can be costly as well, resulting in restrictions on the payment of dividends, limitations on merger activity, and other adverse consequences. ${ }^{51}$ Thus, an accounting choice, an operational decision, or a mandatory change in accounting standards that reduces earnings, even if the earnings reduction is completely cosmetic, reduces firm value by increasing the risk of costly debt covenant violation. As Richard Leftwich points out, reduction in firm value should not exceed the lesser of the cost of renegotiating the covenants, redeeming the debt (if possible), default, or adjusting operations to avoid default. ${ }^{52}$ Unless renegotiation is costless, however, an income-reducing accounting change will reduce the value of a firm with outstanding debt to some extent.

However, the various contracting costs that have been identified do not all run in the same direction. There are various stories about the effect of accounting and earnings changes on regulation. Watts and Zimmerman postulate that firms would wish to keep reported earnings low to stave off tax increases, suggesting that income-reducing standard changes or accounting choices would reduce political costs. ${ }^{53}$ If renegotiation of executive compensation agreements is costly, mandatory accounting changes that reduce reported earnings will be resisted by management, but the effect on firm value is ambiguous. At one level reducing reported earnings in an environment of sticky compensation contracts should increase firm value by reducing compensation payments. On the other hand, reducing incentive compensation could adversely affect firm value. The optimal contracting story has no directional prediction. Under this theory, mandatory standard changes that reduce accounting choices reduce firm value whether the new standard results in higher or lower reported earnings. ${ }^{54}$

\section{Shareholder and Manager Appetite for Earnings}

In the absence of transaction costs, cosmetic accounting changes would have no impact on share value, and loyal directors would simply ignore the impact of their decisions on reported earnings. The decision to sacrifice cash flow for earnings, as in Kamin, would clearly run counter to shareholder interests. Once we introduce positive accounting theory, however, the picture is more complex. Assuming that contracting costs are non-trivial, loyal managers would need to balance earnings effects against other cash flow effects, and even cosmetic changes in accounting could affect share value.

Let's assume that debt covenant costs dominate other contracting costs so that a reduction in reported earnings resulting from operational decisions or a mandatory

${ }^{49}$ See Richard Leftwich, Evidence of the Impact of Mandatory Changes in Accounting Principles on Corporate Loan Agreements, 3 J. ACCT. \& ECON. 3, 6 (1981).

${ }^{50}$ See id. at 8 .

${ }^{51}$ See id. at 6.

${ }^{52}$ See id. at 7.

${ }^{53}$ See WatTs \& Zimmerman, supra note 13, at 231. Cf. Simon Romero \& Edmund L. Andrews, At Exxon Mobil, a Record Profit but No Fanfare, N.Y. TIMES (Jan. 31, 2006) (covering Exxon Mobil's announcement of a record $\$ 36$ billion in annual profits and efforts by the company to play down the news).

${ }^{54}$ See WATTS \& ZIMMERMAN, supra note 13, at 219. 
change in accounting standards reduces firm value. Share value maximization would require managers to take these costs into account. But there are conflicting forces. As in Kamin, steps taken to increase reported earnings often result in increased taxes, and vice versa. A proposed change in accounting standards may decrease reported earnings and increase the expected cost of default on debt covenants, but opposing the change may entail monetary and perhaps political costs. Thus, while shareholders will have some appetite for accounting-induced increases in reported earnings, this appetite will be tempered by other costs. Share value will be maximized by maximizing after-tax cash flow, but this requires striking a balance between the contracting costs associated with reported earnings and other cash flow effects. The optimal point on the continuum between earnings maximization and maximization of other cash flows will depend on firm characteristics. For example, firms that are highly leveraged will face relatively greater costs from reduced reported earnings. Of course, even calculating the optimal point along this continuum is costly, and for some firms share value may indeed be maximized by simply ignoring the effect of reported earnings (perhaps the case for unleveraged companies) or by maximizing reported earnings and ignoring cash flow (unlikely, but conceivably the case for highly leveraged firms in the vicinity of insolvency).

In a world without agency costs, managers' appetite for reported earnings would mirror that of shareholders, but in the real world, we should expect managers to have a stronger appetite for earnings than shareholders. First, and most obviously, managerial compensation may depend on reported earnings, independent of the effect of earnings on share price. Accounting-based bonuses have a long pedigree and remain common today. ${ }^{55}$ Reported earnings often factor into managerial bonuses both as an element in bonus calculations and as a ceiling on bonus payouts. ${ }^{56}$ In recent years, of course, equitybased compensation has grown to overshadow traditional bonuses (although accountingbased bonuses generally have not been reduced, much to the consternation of corporate pay critics). ${ }^{57}$ However, the latest trend is to tie receipt of equity-based pay to accounting performance, increasing the sensitivity of managerial compensation to financial accounting. Thirty percent of major U.S. corporations recently surveyed by Mercer Consulting based a portion of CEO equity compensation on the achievement of accounting-based performance targets. ${ }^{58}$ For example, stock option grants increasingly

${ }^{55}$ See Susan Eichen \& Eric Scoones, Annual Incentive Plan Design Considerations, in EXECUTIVE COMPENSATION 35, 37, 49-50 (Yale D. Tauber \& Donald R. Levy eds., 2002) (noting that "vast majority" of U.S. companies maintain annual incentive plans and that financial measures of performance, principally income-based measures, are among the most commonly used metrics in these plans).

${ }_{57}^{56}$ See Jerold L. ZimMERMAn, ACCOUNTING FOR DECISION MAKING AND CONTROL 185 (1995).

57 According to a recent study, equity-based compensation accounted for $72 \%$ of total compensation paid to the top five executives of S\&P 500 companies in 2000 and 2001, and then declined to $55 \%$ of total compensation for 2003 , the last year of data reported. This study also found that although average equity-based pay received by CEOs of S\&P 500, Mid-Cap 500, and Small-Cap 600 companies about tripled between 1993 and 2003, cash compensation still increased by about 40\% across this period. See Lucian Bebchuk \& Yaniv Grinstein, The Growth of Executive Pay, 21 OxFORD REV. ECON. POLICY 283, 290-92 (2005).

58 See Joann S. Lublin, Boards Tie CEO Pay More Tightly to Performance; Options Grants May Depend on Meeting Financial Goals: Moving Beyond a "Pulse”, WALL ST. J., Feb. 21, 2006, at A1. 
are made contingent on a corporation's achievement of earnings, revenue growth, or other financial targets. 59

In addition, high reported income may have an indirect effect on a manager's compensation. Even if information presentation has no direct effect on stock prices and little or no direct effect on compensation, managers may be able to use high reported earnings as a factor in negotiating additional compensation. Compensation consultants working for senior executives are masters at identifying the metrics that allow their bosses to report better than average performance, justifying higher than average compensation. ${ }^{60}$ Artificially inflating reported earnings is one way to shine relative to one's peers.

Positive accounting theorists have long recognized that managers of firms with earnings-based bonuses will tend to choose earnings-increasing accounting practices and favor earnings-increasing standards. ${ }^{61}$ The more general point that even executives of companies that lack explicit earnings-based bonuses will share these motivations has not been widely recognized in the accounting literature, perhaps because it is a difficult proposition to test. However, it is important to recognize the difference between this story and the contracting and political cost stories. Assuming that accounting-induced increases in executive compensation do not provide commensurate increases in productivity, an earnings-increasing change in accounting standards or practices tends to reduce share value because of the increased compensation payout. But despite the reduction in share value, the executive decision makers may very well favor the change because they receive a portion of the increased compensation that results. Here there is a divergence of interests between managers and shareholders that does not arise in examining the impact of reported earnings on debt contracts or political costs. This is still a transaction cost story, but in the agency cost vein. ${ }^{62}$

Second, in some cases, managers may care less about the compensatory effects of reported earnings per se, and more about the increased exposure to scrutiny of certain elements of their compensation. The FASB's decision to require companies to shift stock option expense reporting from footnote to front page will reduce reported earnings and thus will reduce earnings-based bonuses and could have negative effects on other forms of compensation. But perhaps more importantly, the new reporting requirement makes option compensation more visible to corporate critics and shareholder advocates, which may result in pressure on directors to limit options. ${ }^{63}$ Thus, resistance to stock option expensing may appear to reflect a stronger managerial appetite for earnings than truly exists.

${ }^{59}$ See id.

${ }^{60}$ See Graef S. Crystal, In SeArCh of ExCESS 42-50 (1991); LuCiAn BebChuK \& Jesse Fried, Pay Without Performance 71 (2004); Lucian Arye Bebchuk et al, Managerial Power and Rent Extraction in the Design of Executive Compensation, 69 U. CHI. L. REV. 751, 790-91 (2002).

${ }^{61}$ See Watts \& Zimmerman, supra note 13, at 138; WATTS \& ZIMMERMAN, supra note 13, at 256.

${ }^{62}$ See Michael C. Jensen \& William H. Meckling, Theory of the Firm: Managerial Behavior, Agency Costs and Ownership Structure, 3 J. FIN. ECON. 305 (1976) (seminal article on the manager/shareholder agency problem).

63 See Dechow et al, supra note 9, discussed infra Part II.C. (empirical study indicating that managerial resistance to stock option expensing proposal was driven by concerns relating to the scrutiny of option compensation), Bebchuk et al, supra note 60 (developing a managerial power model of executive compensation and arguing that salience is a critical factor limiting compensation). For further discussion, see infra notes 106-111 and accompanying text. 
Third, some managers may hold an honest, but mistaken belief that information presentation directly affects stock prices. They may subscribe to the naïve investor view of the market that runs counter to the semi-strong version of the ECMH, and holds that investors take earnings at face value and reward firms that report high earnings with high share prices. Obviously, managers that honestly thought that reported earnings directly affected their stock price would place a high value on increasing those earnings.

Fourth, managers may be socialized into placing inordinate importance on earnings, achieving earnings targets, and maintaining steady earnings improvements by the focus of stock analysts on these metrics. Of course, all else being equal, higher earnings should translate into a higher stock price. One can easily imagine, however, that over time high earnings could become a goal in and of itself.

There are no obvious reasons why managers would have less of an appetite for earnings than shareholders, or at least no systematic reasons. ${ }^{64}$ At times, accounting results may provide an excuse or cover for managers to achieve other objectives, and excuses may be predicated on earnings-decreasing changes in accounting. For example, a 1990 change in accounting for post-retirement health care benefits resulted in a substantial increase in reported expenses. ${ }^{65}$ The implementation of this change was followed by massive cuts in these benefits. The accounting change may have provided the political cover needed to implement these cuts. However, this Machiavellian story is undermined by the observation that managers vociferously opposed the adoption of this accounting standard. ${ }^{66}$ Moreover, the excuse theory works both ways. As noted above, managerial resistance to stock option expensing, an earnings-decreasing change, may have arisen in part from a desire to minimize the salience of managerial compensation.

Given the directional ambiguity of the accounting-as-excuse story and all the other reasons for managers to have a stronger appetite for earnings than shareholders, we should expect the distribution of managerial preferences along the continuum between maximizing reported earnings and maximizing other cash flows to be skewed in the direction of earnings maximization, relative to shareholder preferences. Assuming a divergence between shareholder and manager preferences, how do firms respond in situations in which earnings and cash flow concerns conflict? The resolution depends on the severity of the managerial agency problem in any given firm, which is a function of incentives and corporate governance. ${ }^{67}$ Perversely, managers of firms that have more

64 Depending on bonus plan structure, managers may have an incentive to reduce reported earnings in a particular period. Imagine that a manager's annual bonus opportunity is dependent on company earnings exceeding a particular threshold and that it becomes obvious that the threshold will not be exceeded for year $\mathrm{X}$. In that case, the manager has an incentive to accelerate expenses from year $\mathrm{X}+1$ to year X. Taking a "big bath" in year X will have no impact on her bonus for that year, but will increase the likelihood of exceeding the earnings threshold and receiving a bonus for year $\mathrm{X}+1$. See, e.g., Timothy W. Koch \& Larry D. Wall, The Use of Accruals to Manage Reported Earnings: Theory and Evidence (Federal Reserve Bank of Atlanta Working Paper, Nov. 2000). Note, however, that the "big bath" phenomenon does not suggest that managers would prefer earnings-reducing accounting standard changes. On balance, managers prefer to report high earnings.

${ }^{65}$ See infra notes 69-71 and accompanying text.

${ }^{66}$ See Stephen A. Zeff, The Evolution of U.S. GAAP: The Political Forces Behind the Professional Standards, THE CPA J., Feb. 2005, at 25-26 (recounting strong opposition by industry to this change in accounting standards but noting that "afterwards, companies conceded its constructive effect on their decision making.").

${ }^{67}$ See Jensen \& Meckling, supra note 62; Bebchuk et al, supra note 62. 
closely linked executive pay to earnings in order to align managerial incentives with those of shareholders are more likely to sacrifice cash flow for reported earnings. ${ }^{68}$ But among firms with similar pay practices, we should expect better governed firms to more closely track shareholder preferences and exhibit relatively less appetite for earnings relative to more poorly governed firms. In fact, one can imagine that in many cases shareholder preferences for earnings per se are negligible, while managerial preferences are considerable, leading to quite different earnings management behavior between well and poorly governed firms. I am not aware of any empirical evidence on this point, and it seems fertile ground for further research. We turn now, however, to consider empirical evidence on the general topic of the behavioral impact of financial accounting.

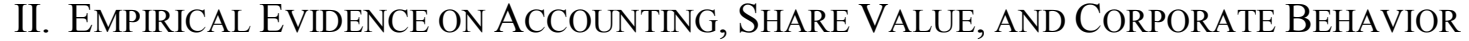

Positive accounting theory provides a rational basis for believing that accounting standards and practices matter, and the empirical evidence generally supports this view. Managers and corporations act as if accounting mattered, and we observe that accounting choices vary systematically between firms. Unfortunately, the empirical evidence supporting details of positive accounting theory is mixed, at best. Evidence of stock price reaction to accounting changes has been found in some studies, but a recent survey of the empirical literature concludes that this evidence is not strong. Managerial and corporate reaction to accounting changes provides stronger evidence of positive accounting theory. Much of this evidence, however, is as consistent with a manager-driven theory of accounting choice as it is with positive accounting theory. None of the evidence is inconsistent with the semi-strong view of the ECMH.

\section{A. Stock Price Reaction to Changes in Mandatory Accounting Standards}

If one is looking for real world effects of accounting, the most obvious place to start is with changes in mandatory standards and market reaction to those changes. Indeed, some studies have found stock price reactions to changes in mandatory accounting standards. For example, in 1990 FASB implemented Statement of Financial Accounting Standards No. 106 (SFAS 106), which replaced pay-as-you-go accounting for post-retirement health care benefits with accrual accounting. ${ }^{69}$ This shift reduced reported earnings for companies offering such benefits. One study of SFAS 106 implementation found that the release of the exposure draft document formally proposing the standard change resulted in a 3\% share price drop for the firms in their sample. ${ }^{70}$ This result appears to provide evidence for the contracting cost hypothesis, and specifically the

${ }^{68}$ This phenomenon demonstrates the intractability of the managerial agency problem. As with the arcade game "Whac-a-Mole," efforts to combat shirking, excessive perquisite consumption and similar agency problems by tying executive pay to financial results can result in unexpected agency problems popping up elsewhere.

${ }^{69}$ See Espahbodi et al, supra note 47.

${ }^{70}$ See id. at 324, 341. Sample firms offering post-retirement benefits experienced a 3\% abnormal negative return compared to a control group of firms not offering such benefits. The authors also found that the negative impact of the new standard on stock prices varied cross-sectionally as expected; e.g., the effect was more pronounced for firms that were at greater risk of default as evidenced by high debt to equity ratios. 
debt covenant hypothesis: Reduced earnings as a result of SFAS 106 implementation would increase the risk of costly default. ${ }^{71}$

By contrast, a study of share price reaction to several key FASB announcements pertaining to stock option expensing found no evidence of systematic market reaction to these announcements. ${ }^{72}$ Expensing of stock options would reduce reported earnings and result in a stock price decrease if the debt covenant effect were dominant. Thus, announcements signaling an increasing/decreasing likelihood of expensing should have resulted in reduced/increased share prices.

In their 1986 book on positive accounting theory, Watts and Zimmerman report that studies investigating stock price reactions to mandated changes in accounting procedures support the theory, but they admit that the associations between variables are inconsistent across studies. ${ }^{73}$ A more recent survey article reviewing twenty six studies of mandated accounted changes published in the top three accounting journals during the 1980 s, concluded that in aggregate these studies provided little or no evidence of stock price effects. The author concluded that the effects were small. ${ }^{74}$ It is also possible, however, that the effects are significant, but difficult to detect because accounting standard changes are not announced out of the blue.

Watts and Zimmerman note that stock price change studies are relatively weak tests of positive accounting theory. ${ }^{75}$ The weakness arises in part because of the difficulty of isolating accounting change announcements that surprise the market. ${ }^{76}$ If one accepts at least the semi-strong version of the ECMH, the actual reporting of higher or lower earnings as a result of a change in accounting standard should have no effect on stock prices. ${ }^{77}$ The market sees through this. The effect on firm value and stock price arises from sticky contracts and the effect of a change in reported earnings on those contracts. Once the market gets wind of a coming change in standards, however, the market can predict the impact of that change on contracting costs in advance of its implementation. Thus, assuming that a standard change is merely cosmetic and has no effect on the information available to the marketplace, the impact of the coming change should be fully incorporated in stock prices when the market is confident that the change

71 See id. The authors also speculated that SFAS 106 may have increased contracting costs generally, by making a poor tradeoff between timeliness and reliability of information provided to the marketplace. Accrual accounting is more timely than pay-as-you-go, but accrual accounting involves estimation that was not necessary under the former standard. See id. at 327.

72 See Dechow et al, supra note 9, at 16. The events tested were the 1993 announcement that the FASB had voted to mandate stock option expensing, the release of the exposure draft mandating expensing about three months later, and the subsequent announcement that the FASB would drop mandatory expensing in favor of voluntary expensing and mandatory footnoting. The study did find significant management reaction to the expensing proposal in the form of comment letters to the SEC objecting to option expensing.

${ }_{73}^{7}$ See WATTS \& ZIMMERMAN, supra note 13, at 311.

74 See V.L. Bernard, Capital Market Research in Accounting During the 1980s: A Critical Review, from the State of Accounting Research as We Enter the 1990s (cited in Fields et al, supra note 22, at 264).

${ }^{75}$ See Watts \& Zimmerman, supra note 13 , at 138.

${ }^{76}$ See Leftwich, supra note 49, at 9-10.

77 This assumes that there is no change in publicly available information. If the accounting change were to make public previously non-public material information, the post-change earnings reports would be informative and would affect stock prices. 
will be implemented. As a result, researchers looking for evidence of market reaction to accounting changes focus on FASB exposure drafts or other announcements of proposed changes. But a price effect would be expected only when the market is surprised. Accounting standard changes that are suggested, debated, announced, revised and reannounced may not result in the degree of surprise that would result in a statistically significant stock price change even if the contracting cost story is right. ${ }^{78}$

It is worth noting, however, that there is no evidence that the implementation of an accounting standard change impacts stock prices. Researchers investigating SFAS 106 implementation, for example, generally agree that the market had fully incorporated the change into stock prices prior to implementation. ${ }^{79}$ This evidence is consistent with semi-strong market efficiency. Under a naïve investor view of the market, stock prices should have been reduced on the promulgation of earnings statements applying the new standard.

\section{B. Corporate Response to Changes in Mandatory Accounting Standards}

Given the difficulty of isolating price responses to accounting standard changes, some studies have focused instead on corporate reaction to these changes. These studies reinforce the view that accounting matters and provide limited support for the positive accounting theory explanation.

For example, SFAS 106, which engineered the switch from pay-as-you-go accounting for post-retirement health care benefits to accrual accounting, had a dramatic effect on firm behavior. ${ }^{80}$ Companies reacted to the new standard by slashing postretirement health care benefits. One study of SFAS 106 implementation found a tight cluster of benefit cuts around the adoption date following 10 years in which cuts were rare, ${ }^{81}$ and concluded that the "data indicate a strong associative relation between the decision to cut retiree health care benefits and the requirement to adopt SFAS No. 106."82

The authors of this study also found evidence supportive of the contracting cost hypothesis. They found that cuts in benefits were related to the extent to which a firm was leveraged prior to adoption of SFAS 106 (a proxy for the tightness of debt covenants) and the extent to which adoption increased that leverage (which proxied for the increased risk of covenant violation). ${ }^{83}$

${ }^{78}$ See Holthausen \& Leftwich, supra note 14 , at 105.

79 See Brian J. Hall \& Kevin J. Murphy, The Trouble with Stock Options, 17 J. ECON. Perspectives 49, 66 (2003) (summarizing studies); see also H. Fred Mittelstaedt et al, SFAS No. 106 and Benefit Reductions in Employer-Sponsored Retiree Health Care Plans, 70 ACCT. REV. 535, 539 (1995) (asking "why managers reduce[d] benefits as a result of SFAS No. 106 if security prices fully reflect[ed] retiree health care liabilities prior to its adoption").

${ }^{80}$ See Mittelstaedt et al, supra note 79.

${ }^{81}$ See id. at 548, tbl 2. Of course, we need to be concerned about causation and potential omitted variable problems. See Ray Ball, Discussion of Accounting for Research and Development Costs: The Impact on Research and Development Expenditures, 18 J. ACCT. RES. 27, 37 (1980) (warning that accounting change studies are suspect because they treat the imposition of a new standard as exogenous, when in fact the new standard, corporate reaction, and stock price changes all may be related to an omitted environmental change).

${ }^{82}$ See Mittelstaedt et al, supra note 79, at 554.

${ }^{83}$ See id. at 542-543, 552. 
However, as suggested above, some observers believe that the relationship between the promulgation of SFAS 106 and benefit cuts is better explained as political cover. ${ }^{84}$ Accrual accounting for these benefits massively increased the expense reported in company financial statements and allowed companies slashing benefits to place the blame on the accountants. ${ }^{85}$ Thus, it is difficult to determine the relative contributions of contracting costs, political cover, and managerial fixation with reported earnings towards the clear corporate behavioral response to SFAS 106.

Similar results were found in an earlier study that investigated corporate response to SFAS 13, which moved capital lease disclosures from financial statement footnotes onto corporate balance sheets. ${ }^{86}$ This move had the effect of increasing debt and reducing reported income, increasing leverage and decreasing reported rates of return. ${ }^{87}$ From either a contracting cost or managerial compensation perspective, this was an unwelcome change. Increased leverage increased the risk of debt covenant default, and managerial compensation often is tied, implicitly or explicitly, to accounting rates of return. ${ }^{88}$ Thus, the authors predicted (and found) that firms would respond by reducing their reliance on capital leases and shifting to operating leases that had better accounting characteristics. ${ }^{89}$ Although the authors demonstrated corporate sensitivity to the negative accounting standard change, they did not test for the positive accounting theory explanations.

\section{Stock Option Expense Accounting}

Of course, the highest profile change in accounting standards to occur in some time was the adoption of mandatory stock option expensing, which is coming into effect in 2005 and $2006 .^{90}$ Many experts predict that this change will result in a significant adjustment in compensation practices, although it is much too early to say. A study of corporate lobbying against the rule's adoption, however, indicates that opposition was driven by management concerns unrelated to real economic effects. ${ }^{91}$ Before turning to this study, however, let us consider another behavioral aspect of the stock option story. As noted above, until 2005 standard compensatory stock options resulted in no reduction in reported earnings, ever, although the compensation expense has been reported in footnotes to earnings statements since 1995. Anecdotal and empirical evidence suggests that this anomalous accounting treatment was a primary factor in the growing use of options in the 1990s. Less clear, however, is whether positive accounting theory or self-

${ }^{84}$ See supra note 66 and accompanying text.

${ }^{85}$ See Mittelstaedt et al, supra note 79, at 538-539.

86 See Eugene A. Imhoff, Jr. \& Jacob K. Thomas, Economic Consequences of Accounting Standards: The Lease Disclosure Rule Change, 10 J. ACCT. \& ECON. 277 (1988).

${ }^{87}$ See id. at 279.

${ }^{88}$ See id.

${ }^{89}$ See id. at 278.

${ }^{90}$ Companies (other than small businesses) are required to record option compensation as an expense in fiscal years beginning on or after June 15, 2005. See SEC Release No. 33-8568. Thus, a company with a fiscal year beginning on June 1 would not be required to report option compensation as an expense until late in 2006.

${ }^{91}$ See DeChow et al, supra note 9. 
serving managerial behavior better explains the incentive effect of stock options accounting.

Practitioners and practice-oriented academics are uniformly of the view that the accounting treatment of stock options is important to executives and has contributed to the explosion in their use. Kevin Murphy, a financial economist and noted executive compensation expert, argues that the increasing prevalence in the 1990s of broad-based stock option plans granting a majority of options to employees below the very top ranks is evidence of option overuse, since only the top executives are in position to significantly influence the firm's stock price. ${ }^{92}$ Murphy attributes excessive use of options to management misperception that options represent inexpensive compensation. ${ }^{93}$ That misperception is based on the fact that options require no cash outlay (although this is also true of stock compensation, which is far less prevalent) and on the fact that, until recently, options did not reduce reported earnings. ${ }^{94}$ Murphy does not believe that the accounting treatment of options has a direct effect on share prices or that management fixation on compensation accounting is based solely on share price effects. "[B] ased on countless discussions (often heated arguments) with compensation consultants, practitioners, and executives, [Murphy] is convinced that ... this fixation reflects more than the effect of accounting rules on stock prices." 96

Murphy believes that "companies would respond ... dramatically to changes in the accounting treatment of stock options." 97 As evidence, Murphy cites data demonstrating that the practice of explicitly reducing the exercise prices of outstanding stock options following market downturns came to an abrupt halt at the end of 1998 when new accounting rules required firms to expense repriced options. ${ }^{98}$

Similarly, Brian Hall and Jeff Liebman echo the view of practitioners that accounting treatment is an important factor in option plan design. ${ }^{99}$ They report that companies often fail to seriously consider stock option plans that have "bad accounting," i.e., result in compensation expense recognition. ${ }^{100}$

Although somewhat mixed, there is a growing body of empirical evidence linking stock option use to its favorable accounting treatment. Because the accounting treatment of conventional stock options was consistent up to 2005, cross sectional analyses have been employed seeking to establish a relationship between option use and the degree to which companies are concerned with financial reporting results. Sensitivity to reported earnings sometimes is estimated directly by looking at variables such as interest coverage or retained earnings. Low interest coverage increases the probability of violating debt covenants and limited retained earnings are likely to result in dividend constraints. These

${ }_{92}^{92}$ See Murphy, supra note 8, at 857-58.

${ }^{93}$ See id. at 859. See also Hall \& Murphy, supra note 79, at 66 (arguing that the result of underestimating the true cost of stock options "is that too many options will be granted to too many people, and options with favorable accounting treatment will be preferred to (perhaps better) incentive plans with less favorable accounting").

${ }_{94}^{94}$ See Murphy, supra note 8, at 857-58.

${ }^{95}$ See id. at 860.

${ }^{96} \mathrm{Id}$.

${ }^{97} I d$.

${ }^{98}$ See id. at 861-62.

${ }^{99}$ See Brian J. Hall \& Jeffrey B. Liebman, The Taxation of Executive Compensation 6, NBER working paper no. 7596 (Mar. 2000).

${ }^{100}$ See id. 
variables are consistent with positive accounting theory and specifically the contracting cost theory. Other studies determine earnings sensitivity indirectly by looking for other evidence of earnings management, such as how consistently a firm beats analyst earnings forecasts. Although these latter studies tell us something about earnings sensitivity, they tell us little about positive accounting theory. Earnings sensitivity in these cases could be driven by self-serving managerial behavior rather than contracting costs.

Of three studies focusing exclusively on option grants to $C E O s$, only one found significant evidence that accounting drives option use. ${ }^{101}$ However, two studies of broadbased option plans both support the view that accounting drives option use, as well as the contracting cost explanation. First, an analysis of all options granted to employees by 123 firms over an eleven year period found a positive relationship between the use of options and other earnings management techniques and between option use and dividend constraints. ${ }^{102}$ And a more recent examination of option grants to executives reported in the Standard and Poor's ExecuComp database yielded the conclusion "that what is driving the use of options in non-CEO compensation is not the need to realign incentives, but the desire to avoid the expense." 103

Although CEOs typically receive the largest option grants within their companies, CEO options typically represent a small percentage of total options granted. ${ }^{104}$ Accordingly, the earnings effect of CEO options alone would be small in comparison to the effect of paying employees with options generally, and it is not surprising that studies looking at broad-based option plans are more informative. Of course, the ultimate test of the importance of option accounting to option use will be in the response of companies to the new option expensing requirement. Already, there is anecdotal evidence of a shift away from options in favor of other forms of equity compensation, such as restricted stock, but it is too early to draw firm conclusions. ${ }^{105}$

The evidence suggests that the pre-2005 stock option accounting rules served as a successful, although unintended, accounting incentive. Even if one accepts this conclusion, however, one can ask whether we can generalize from this. There is some evidence consistent with a positive accounting theory explanation for accounting-driven option use, but other evidence simply indicates that accounting matters, without really

101 Compare John Core \& Wayne Guay, The Use of Equity Grants to Manage Optimal Equity Incentive Levels, 28 J. ACCT. \& ECON. 151, 173 (1999) (finding a significant and positive relationship between option use and dividend constraints) with David Yermack, Do Corporations Award CEO Stock Options Effectively?, 39 J. FIN. ECON. 237, 264 (1995) (finding no significant relationship between option use and financial reporting costs) and with Stephen Bryan et al, CEO Stock-Based Compensation: An Empirical Analysis on Incentive-Intensity, Relative Mix, and Economic Determinants, 73 J. BUS. 661,683 (2000) (finding evidence of a significant link between options use and some measures of financial reporting costs, but not others).

${ }^{102}$ See Steven R. Matsunaga, The Effects of Financial Reporting Costs on the Use of Employee Stock Options, 70 ACCT. REV. 1, 23 (1995).

${ }^{103}$ Mary Ellen Carter et al, The Role of Incentives and Accounting in the Design of Executive Compensation Packages 24 (working paper, Aug. 2004) (emphasis in original).

104 See, e.g., Hall \& Murphy, supra note 79, at 51 (finding that the value of options granted to CEOs of S\&P 500 firms averaged about 7\% of the total value of options granted in the mid-1990's, but had fallen to less that $5 \%$ in 2000 to 2002).

${ }^{105}$ See Michael S. Knoll, Restricted Stock and the Section 83(b) Election: A Joint Tax Perspective 2 (working paper, Aug. 2005) (citing survey evidence indicating a shift from stock options to restricted stock). 
telling us why. Moreover, there is an additional reason to suspect that self-serving managerial behavior played an important role in the use of options under the pre-2005 accounting regime. Managers may care excessively about reported earnings generally, but even if they do not, they might prefer that stock options not be expensed (and might over-rely on options given the pre-2005 accounting treatment), because "footnoting" option compensation helped to camouflage their own compensation.

Two colleagues and I have argued that U.S. executive compensation practices reflect in large part a managerial power view of corporate governance. ${ }^{106}$ Under this theory, executive compensation is not set by efficient contracting, but is largely controlled by the managers themselves, subject to market forces and to investor and financial press outrage that tends to constrain directors and the managers themselves. ${ }^{107}$ Under this theory, compensation transparency is the manager's enemy, and compensation channels that are less visible or camouflaged will be preferred. ${ }^{108}$

There is some evidence that accounting camouflage plays a role in stock option use. Although options are often granted far down into the employee ranks, the value of options often is concentrated at the very top. One study found evidence that corporate opposition to the 1993 FASB proposal to mandate stock option expensing was driven by top executives' concerns relating to the scrutiny of their compensation and not by real economic effects. ${ }^{109}$ Specifically, the study found that top executives of companies submitting comment letters to the FASB opposing the change tended to receive a greater fraction of their total pay through options and more pay in total than executives of similar non-commenting firms. ${ }^{110}$ In addition, it found that option programs were more "top heavy" in commenting firms relative to their non-commenting peers. ${ }^{111}$ This evidence suggests that the stock option accounting "incentive" may have been more effective than simple earnings fixation would suggest.

\section{Voluntary Accounting Choice Evidence - Tax/Earnings Tradeoffs}

Every day, managers make choices between permissible accounting techniques and make operational decisions that have significant accounting consequences. The choice to employ stock options in lieu of other forms of compensation provides one example of voluntary accounting choice writ large. Studies of voluntary accounting choices demonstrate that accounting is not irrelevant. This literature is voluminous. Instead of attempting to provide an overview, I will direct the reader to any of several good survey articles noted in the margin, ${ }^{112}$ and focus here, by way of example, on the literature examining company tradeoffs between minimizing taxes and boosting reported earnings. This literature is typical of voluntary accounting choice studies, demonstrates accounting relevance, and provides some evidence of positive accounting theory.

${ }^{106}$ See Bebchuk et al, supra note 60; see also BEBCHUK AND FRIED, supra note 60.

107 See Bebchuk et al, supra note 60, at 786-88.

108 See id. at 789.

${ }^{109}$ See Dechow et al, supra note 9, at 2.

${ }^{110}$ See id.

111 See id.

112 See Fields et al, supra note 22; Douglas A. Shackleford \& Terry Shevlin, Empirical Tax Research in Accounting, 31 J. ACCT. \& ECON. 321 (2001). 
Although financial and tax accounting rules differ in many respects, managers often face a conflict between minimizing taxes and maximizing earnings. Actions that reduce taxable income and taxes often result in lower financial statement income as well. If accounting were irrelevant, we would expect managers to ignore reported earnings and minimize taxes in order to maximize after tax cash flow. Instead, we often see managers sacrificing cash flow for reported earnings improvements.

The Kamin case, discussed above, is a prime anecdotal example of this effect. There, recall, the directors apparently forewent potential tax savings of $\$ 8$ million to avoid a \$26 million reduction in reported earnings. ${ }^{113}$ The decision to distribute the depreciated securities to the shareholders rather than sell them and distribute the cash proceeds in Kamin apparently had no other consequence.

We should be careful not to read too much into this example. First, the case was decided on a summary judgment motion made by the American Express defendants, which required the judge to accept the facts as presented by the plaintiffs. Normally, we should be highly suspicious of the facts presented in this circumstance. However, the opinion suggests that minutes of the relevant directors' meeting essentially confirmed the facts alleged by the plaintiffs. ${ }^{114}$ Second, this is a single isolated case. Nonetheless, practitioners generally are not surprised by the action of the American Express board in this case and find it consistent with their experience. ${ }^{115}$ It is also consistent with empirical studies of asset divestitures, as discussed below.

If the facts are taken as given in the opinion, the Kamin case squarely presents a tradeoff between tax savings and earnings management. Although somewhat less clean, two empirical studies of asset divestitures support the view that managers sacrifice tax benefits and cash flow to boost earnings when disposing of assets, but provide only limited support for positive accounting theory. One study investigated taxable sales versus non-taxable spin-offs of corporate subsidiaries. ${ }^{116}$ Just as the American Express directors faced a choice between selling the depreciated securities and distributing them to shareholders, directors of a company wishing to dispose of a subsidiary can sell it or distribute its stock to shareholders through a spin-off. If managers focused solely on tax minimization, they would spin-off subsidiaries if a sale would result in a taxable gain and sell subsidiaries if a sale would result in a tax loss. Instead, this study demonstrated that managers routinely incurred avoidable tax costs or forwent potential tax benefits in structuring divestments. ${ }^{117}$ Of course, there could be many reasons other than tax and financial reporting considerations for structuring a divestment as a sale or spin-off - a sale generates cash, while a spin-off does not; a sale may yield a premium price if the asset is worth more in the hands of the buyer. Nonetheless, the evidence was consistent with the view that managers trade off tax against earnings, and the authors estimated that firms were willing to incur $\$ 0.19$ of extra tax costs to boost earnings by $\$ 1 .^{118}$ This study

${ }^{113}$ See Kamin, 383 N.Y.S.2d at 809-810.

${ }_{114}^{11}$ See id.

${ }^{115}$ See, e.g., Conversations from the Warren Buffet Symposium (Lawrence A. Cunningham, ed.), 19 CARDOZO L. REV. 719, 794-800 (1997) (discussing Kamin and more egregious examples of the phenomenon).

${ }^{116}$ See Edward L. Maydew et al, The Impact of Taxes on the Choice of Divestiture Method, $28 \mathrm{~J}$. ACCT. \& ECON. 117 (1999).

${ }^{117}$ See id. at 120.

${ }^{118}$ See id. at 146. 
provided little evidence of positive accounting theory. The results were only "weakly consistent" with a contracting cost variables. ${ }^{119}$

Another study of major asset divestitures confirms that managers weigh both taxes and the impact on reported income in making divestitures. ${ }^{120}$ This study finds that firms with greater inside ownership concentration are less likely to sacrifice tax benefits in an effort to boost reported earnings. ${ }^{121}$ The author suggests that high inside ownership concentration reduces capital market pressures on a firm. That may be so, but it is unclear how this reduced capital market pressure fits into positive accounting theory. That theory holds that shareholders are sensitive to earnings because of sticky contracts based on those earnings. Perhaps high inside ownership concentration reduces the cost of renegotiating executive compensation contracts, but it is unclear what effect inside ownership would have on debt covenants, which most researchers consider the dominant factor. It seems much more plausible that firms with high inside ownership focus more on after-tax cash flow, because manager and shareholder interests are more closely aligned. This evidence supports the view that the appetite for earnings found in many of these studies is driven by manager preferences in lieu of or in addition to shareholder preferences consistent with positive accounting theory.

Kamin and the asset disposition studies certainly demonstrate management sensitivity to reported earnings. But these cases involve discrete, one time events, and questions of investment, disposition, or payout policy, not day-to-day operations. One may question whether earnings effects influence corporate behavior with respect to more day-to-day operational decisions.

A number of studies have evaluated how firms trade off tax minimization against financial reporting considerations with respect to routine, day-to-day activities. One review study summed up the evidence as follows: "In short, the literature suggests that financial accounting management and tax management are not independent and neither consideration consistently dominates the other in decision-making." ${ }^{122}$ In other words, to a greater or lesser extent, managers trade off taxes for earnings. Again, rather than reviewing a large sample of such studies, I will focus on just one example involving disqualification of incentive stock options (ISOs) and leave the interested reader to peruse the review studies cited in the notes. ${ }^{123}$ The ISO disqualification evidence is consistent with what we have seen before - accounting matters, but evidence supporting positive accounting theory explanations of accounting relevance is mixed.

Compared with nonqualified stock options, ISOs provide tax benefits for optionees, but result in tax costs for issuers. ${ }^{124}$ In some cases, depending on various tax rates and the amount of appreciation in the stock underlying the ISO, it makes economic sense for companies and employees to agree to arrange dispositions that will disqualify

${ }^{119}$ See id. at 138 .

120 See Kenneth J. Klassen, The Impact of Inside Ownership Concentration on the Trade-Off Between Financial and Tax Reporting, 72 ACCT. REV. 455 (1997)

${ }^{121}$ See id. at 472.

${ }^{122}$ See Shackelford \& Shevlin, supra note 112, at 327.

123 In addition to Shackelford \& Shevlin, supra note 112, useful reviews of the tax/earnings tradeoff literature can be found in Fields et al, supra note 22, Maydew et al, supra note 116, and MYRON S. SCHOles ET AL, TAXES AND Business PlanNING (2nd ed. 1992).

${ }^{124}$ See SCHOLES ET AL, supra note 123, at 191-92. 
options for ISO treatment. ${ }^{125}$ At times the tax benefit to a company from disqualification is more than sufficient to reimburse an employee for her additional tax cost. This reimbursement, however, must be recognized as an expense, which reduces reported income. $^{126}$

Matsunaga, Shevlin, and Shores investigated ISO exercise and disqualification by 170 companies between 1982 and 1991 and estimated whether disqualification would have resulted in a net tax benefit for the companies and their employees. ${ }^{127}$ The authors determined that in over half of the cases in which there was a net tax benefit, firms failed to disqualify options. ${ }^{128}$ The authors concluded that firms trade off tax benefits against reported earnings. ${ }^{129}$ Cross-sectional analysis of firms that did and did not disqualify ISOs yielded some evidence supporting positive accounting theory. The net tax benefit tended to be larger when options were disqualified; and non-disqualifying firms tended to be more highly leveraged, and thus would have faced higher debt covenant costs had they disqualified their ISOs. ${ }^{130}$

As a final egregious example of companies sacrificing taxes for earnings, consider a recent study of firms that restated financial statements between 1996 and 2002 as a result of SEC accusations of accounting fraud. ${ }^{131}$ This study found that the mean firm paid $\$ 11.85$ million in taxes on the phantom earnings, or about $\$ 0.11$ for each dollar of inflated earnings. ${ }^{132}$ Hopefully, these results are not typical. Managers who are willing to commit fraud to inflate earnings probably are less concerned about shareholder value than honest managers. Nonetheless, the study emphasizes the obsession of some managers with reported earnings.

\section{DoEs ACCOUNTING MATTER? SYNTHESIS OF THE THEORY AND EVIDENCE}

There can be little doubt that accounting matters. There is strong evidence that managers are sensitive to reported earnings and sacrifice cash flow, as in Kamin, to boost earnings, and that changes in mandatory accounting standards affect corporate behavior. However, evidence of systematic variation in discretionary accounting choices and in corporate responses to mandatory accounting standard changes consistent with positive accounting theory is mixed. As the studies sampled in the previous Part indicate, the debt covenant hypothesis is perhaps the best supported of the contracting cost theories, ${ }^{133}$ but even with respect to the influence of debt, a recent survey article concludes that the empirical results are inconclusive. The data suggest a relationship between debt and

${ }^{125}$ See id. at $196-97$.

${ }^{126}$ See id. at 197.

${ }^{127}$ See Steve Matsunaga et al, Disqualifying Dispositions of Incentive Stock Options: Tax Benefits Versus Financial Reporting Costs, 30 J. ACCT. RES. 37, 50-52 (1992).

${ }^{128}$ See id. at 63 tbl 6.

${ }^{129}$ See id. at 66.

${ }^{130}$ See id. at 63 tbl 6.

${ }_{131}$ See Merle Erickson et al, How Much Will Firms Pay for Earnings That Do Not Exist?: Evidence of Taxes Paid on Allegedly Fraudulent Earnings, 79 ACCT. REV. 387 (2004).

${ }^{132}$ See id. at 389.

${ }^{133}$ A review of the voluminous positive accounting theory literature leads one to conclude that despite the inconclusive empirical evidence most researchers view the debt covenant hypothesis as the most significant of the contracting cost theories developed thus far. 
accounting, the authors say, but "we cannot draw definitive inferences."134 Given the weakness of the stock price reaction studies, it is plausible, perhaps likely, that accounting choice, lobbying against earnings-reducing standard changes, and reaction to mandatory standard changes reflects self-serving management behavior as much or more than concern with contracting costs generally.

Perhaps we should not be too surprised that the evidence supporting the positive accounting theory explanation is not stronger. There are several reasons to think that the impact of contracting costs would be limited. Consider changes in mandatory accounting standards and the effect of these changes on contracting costs. At most, a shift from mandatory standard $A$ to standard $B$ that results in lower reported earnings should have a one-time effect on existing debt covenants. Renegotiation of existing covenants may be costly, but the adoption of standard $B$ in place of standard $A$ should have little effect on new debt agreements. ${ }^{135}$ This is also true of executive compensation contracts. New agreements should be as easily tuned to standard $B$ as $A$. The only persistent effect under this theory has to do with political costs. Changes that reduce reported earnings could have a lasting effect on regulation if regulators are slow to adjust their perception of what constitutes normal or excess earnings.

Recall, also, that the impact of accounting change or accounting choice on debt covenants is not necessarily equal to the increase in the expected cost of default. ${ }^{136}$ Other options for dealing with the increased risk, such as renegotiating the covenants or making operational changes to offset all or part of the increased risk, may be less costly. ${ }^{137}$ In addition, as noted above, the contracting cost story does not result in an unambiguous prediction regarding stock prices. ${ }^{138}$ Reduced reported earnings should increase the risk of costly default on debt covenants but also reduce exposure to increased corporate taxes or provide other political benefits. The effect on executive compensation is ambiguous in itself. The conflicting effects decrease the chances of finding significant results.

So this brings us back to our original questions. Having reviewed the theory and empirical evidence, what can we say about Kamin? What can we say about managerial opposition to expensing stock option compensation? What can we say about the likely effects of increased book-tax conformity or the potential for instrumental revision of accounting standards to shape corporate behavior? This Part addresses the first two questions. The remaining questions require significant elaboration and are examined in Parts IV and V.

\section{A. Kamin v. American Express}

${ }^{134}$ Fields et al, supra note 22 , at 26.

${ }^{135}$ If standard $B$ results in less efficient contracting than standard $A$, there will be some persistent loss. If the standards are arbitrary (such as depreciation methods) or equally useful for contracting there will be no persistent effect. Of course, restricting choice among acceptable accounting procedures can be costly, but switching between mandatory standards is unlikely to be.

${ }^{136}$ Of course, many companies may be on such secure footing that the increase in expected cost of default resulting from an earnings-decreasing change in accounting is truly negligible. But these cases do not pose a problem for positive accounting theory or the empirical studies considered which rely on crosssectional analysis of firms exhibiting a broad range of financial health.

${ }^{137}$ See supra note 52 and accompanying text.

${ }^{138}$ See Espahbodi et al, supra note 47, at 324. 
As for Kamin, the American Express directors justification for distributing the depreciated DLJ shares, as reflected in the board minutes and reported by the judge in the case, was that a \$26 million "reduction of net income would have a serious effect on the market value of the publicly traded American Express stock."139 This seems highly unlikely. First, as discussed above, even if one is skeptical of the efficiency of U.S. stock markets, it is very hard to imagine that in this case the market had not already adjusted American Express's stock price to reflect the unrealized loss on such a large, discrete, publicized investment. ${ }^{140}$ Direct price effects are improbable.

Second, it is difficult to believe that contracting costs related to debt covenants drove the decision to distribute the securities and forego the tax benefit. In order for this to have been a rational decision in accordance with positive accounting theory, one would have to conclude that a one-time \$26 million earnings hit increased the expected cost of technical debt default by $\$ 8$ million and that renegotiating debt covenants to account for this charge to earnings would have cost $\$ 8$ million or more. Moreover, the political cost story runs counter to the directors' decision. According to Watts and Zimmerman, companies prefer to report lower earnings to stave off tax increases or other political costs. ${ }^{141}$ That leaves us with employment contract effects. Reported earnings apparently factored into the compensation of some of the inside directors (and presumably other employees). If these agreements are sticky, reducing reported earnings could have costs (lower productivity) and benefits (lower compensation paid), but in all likelihood the net compensation effect of reduced reported earnings would have been positive for shareholders. In any event, it seems highly unlikely that the combination of contracting costs resulting from the one-time charge against earnings could have approached $\$ 8$ million.

It is much more likely that Kamin is a case of managerial preferences for earnings far exceeding shareholder preferences and managers acting on those preferences, in other words, a classic agency problem. It would be nice to be able to say (as I have done in my corporate law class for several years) that the directors' decision in Kamin was unambiguously against shareholder interests, but we cannot honestly say that, given our current understanding of accounting theory. However, the burden should have been on the directors to explain how the indirect effects of a one-time earnings hit could offset the tax benefits foregone. Rather than relying on a general statement about "serious" market effects of a reduction in net income, the onus should have been on the directors and their experts to explain why an accounting-driven reduction in earnings would have a serious effect. Was the company very highly leveraged? Would the earnings reduction have triggered technical default? Was renegotiation of debt covenants or other alternatives to foregoing the tax benefit considered? What were the costs of these alternatives? If management is unable to provide a cost/benefit analysis at least plausibly justifying a

139 See Kamin, 383 N.Y.S.2d at 811.

140 Even Lynn Stout, who is skeptical of the informational efficiency of markets, admits that "[i]nformation that is easy to understand and that is trumpeted in the business media ... may be incorporated into market prices almost immediately." Stout, supra note 28, at 656.

${ }^{141}$ See WATTS \& ZIMMERMAN, supra note 13, at 223; Ross L. Watts \& Jerold L. Zimmerman, Towards a Positive Theory of the Determination of Accounting Standards, 53 ACCT. REV. 112, 115 (1978). 
decision to sacrifice tax benefits for earnings, that decision should not be protected from judicial scrutiny under the prevailing corporate law standard. ${ }^{142}$

\section{B. Managerial Opposition to Stock Option Expensing}

Similarly, managerial opposition to stock option expensing cannot be dismissed out of hand as antagonistic to shareholder interests given our current knowledge of accounting theory. We can be fairly certain that moving fully disclosed stock option expense from footnote to income statement can have no direct effect on stock prices, but the change surely will involve some contracting costs. If the debt covenant costs associated with this earnings-reducing change exceed the political and employment cost savings, some reduction in share prices should be expected. And, unlike the Kamin situation, there is no tax or other direct financial benefit associated with the accounting change to offset the increased contracting costs. ${ }^{143}$ So, at one level, managerial opposition to the change seems rational.

However, there are reasons to suspect that managerial opposition to option expensing exceeds the indirect effect of the standard change on share value. First, although the standard change would be permanent, debt and compensation agreements are not. The contracting costs associated with the change can only arise from existing agreements. New debt agreements and employment contracts can be as easily and cheaply tied to the new accounting regime as the old one. Second, as in Kamin, political and employment effects associated with the change presumably would be positive and offset the other contracting costs to some extent. Third, we should not forget the evidence that managerial opposition to the 1993 option expensing proposal apparently reflected concerns with increased management pay exposure rather than contracting costs, or the evidence from the tax/earnings trade off literature suggesting that managerial

${ }^{142}$ Unfortunately, the legal burden on directors in case like Kamin is minimal. In most U.S. jurisdictions, unless there is clear self-dealing, courts defer to the rational business judgment of the directors. See Robert Charles Clark, Corporate LAW 123-25 (1986). However, in order to earn the protection of the "business judgment rule," the directors must demonstrate, inter alia, that they were reasonably informed with respect to the matter. See ALI Principles of Corporate Governance $\S 4.01$ (c). The shareholders' argument in a future case like Kamin should be that directors who rely on unsupported assertions that purely accounting-driven earnings reductions impair share value have not earned the protection of the business judgment rule because they have not made themselves reasonably informed in light of the theory and evidence. However, given the resistance of courts to second guess managerial decisions and additional statutory protections for managers, particularly in Delaware, I am not optimistic about the prospects for such a suit. See, e.g., In re the Walt Disney Company Derivative Litigation, No. Civ.A. 15452, 2005 WL 2056651 (Del. Ch. Aug. 9, 2005) (finding that although "many aspects of defendants' conduct ... fell significantly short of the best practices of ideal corporate governance," the Disney directors' decision to hire Michael Ovitz as company president and provide him with an employment contract that purportedly paid Ovitz $\$ 140$ million when his employment was terminated about a year later was at most ordinarily negligent and thus the defendant directors were insulated from liability in accordance with the business judgment rule); DGCL $\S 102(\mathrm{~b})(7)$ (permitting Delaware companies to include in their charters exculpatory "provision[s] eliminating or limiting the personal liability of a director to the corporation or its stockholders for monetary damages for breach of fiduciary duty as a director," with exceptions for, inter alia, breaches of duty of loyalty and "acts or omissions not in good faith").

${ }^{143}$ This is not to say that there is no benefit to shareholders from rationalizing compensation accounting. Assuming that managers are utilizing options excessively because of their favorable accounting treatment, a level playing field should result in a more efficient mix of compensation. 
preferences for high reported earnings often overcome apparently more significant cash flow considerations.

\section{BOOK-TAX CONFORMITY}

U.S. public companies maintain separate tax and financial accounts, prepared under different rules and producing different results. The administrative cost of maintaining multiple sets of books has long been recognized, but justified as necessary given the differing purposes of and audiences for tax and financial reports. ${ }^{144}$ In recent years, however, the focus has been on the growing gap between earnings reported to investors (relatively high) and income reported to the taxing authorities (relatively low) and suspicion that part of this gap represents inappropriate tax avoidance and/or earnings inflation. ${ }^{145}$ Of course, part of the gap flows from explicit tax incentives, such as accelerated tax depreciation, or from recognized financial accounting anomalies, such as the failure to record compensatory stock options as an expense. It is widely believed, however, that these deviations represent only part of the gap. ${ }^{146}$ Reformers argue that tax shelters and earnings inflation schemes tend to rely on discontinuities between book and tax accounting. Companies seek out techniques that will allow them to report less taxable income without reducing reported earnings and they prefer earnings enhancement schemes that do not result in increased taxable income. ${ }^{147}$ Eliminating these discontinuities, it is argued, would tend to discourage these activities. ${ }^{148}$ In a world of full conformity between financial and tax accounting rules, companies could not inflate earnings without paying additional taxes and could not cut taxes without cutting earnings as well.

Of course, no one suggests that even full book-tax conformity would be a panacea. Even faced with a tradeoff, firms may inappropriately shelter income from tax or inflate earnings. In Kamin, the book and tax treatment of the disposition of the shares were in conformity. American Express faced a tradeoff between minimizing taxes and maximizing reported earnings, and chose the latter. Of course, Kamin did not involve accounting fraud or tax sheltering, but the suggestion is that without the counterweight

${ }^{144}$ See Thor Power Tool Co. v. Commissioner, 439 U.S. 522, 542 (1979) (discussing differing goals of and audiences for financial and tax accounting).

${ }^{145}$ See Lillian F. Mills \& George A. Plesko, Bridging the Reporting Gap: A Proposal for More Informative Reconciling of Book and Tax Income, 56 NAT. TAX J. 865, 867-868 (2003) (providing data on the increasing ratio of book income to taxable income between the early 1970s and late 1990s and citing other studies providing evidence of an increasing gap in the 1990s); Hanlon \& Shevlin, supra note 11, at 2 (citing studies finding increasing divergence between book and tax income and noting concern that the difference may be caused by misleading or fraudulent reporting of book income, tax income, or both); George K. Yin, How Much Tax Do Large Public Corporations Pay?: Estimating the Effective Tax Rates of the S\&P 500, 89 VA. L. REV. 1793, 1798 (2003) (confirming conclusions of previous studies finding increased gap between book and taxable income in the late 1990s).

${ }^{146}$ See, e.g., Mihir A. Desai, The Divergence Between Book and Tax Income, in 17 TAX POLICY AND THE ECONOMY (James M. Poterba ed., 2003) (arguing that differences arising from the disparate treatment of depreciation, stock options, and foreign source income do not explain the entire book-tax difference and suggesting tax sheltering as the likely explanation for the residual difference).

${ }_{148}^{147}$ See, e.g., Yin, supra note 10, at 225.

${ }^{148}$ See id. 
provided by conforming book and tax accounting treatments, companies are more likely to stretch the rules in seeking to maximize earnings and minimize tax.

The pros and cons of increased book-tax conformity have been widely debated. ${ }^{149}$ However, the behavioral impact of accounting standards has not been fully considered by the participants in this debate. This Part argues that the behavioral effects would be largely negative. These negative effects represent an underappreciated cost of book-tax conformity and provide reason to prefer the alternative of increased disclosure and reconciliation between financial and tax accounts.

\section{A. Book-Tax Conformity Proposals}

Book-tax conformity could be advanced in many ways. Full conformity could be achieved by assessing corporate taxes on income reported under GAAP, or by requiring that financial accounts be prepared consistent with the Internal Revenue Code. Both financial and tax accounting could be based on a compromise set of rules between the current tax code and GAAP. Other options include using one of the foregoing as a baseline for both tax and financial reporting but providing for specific deviations for one of the two sets of books. The most common proposals advocate a partial conformity approach utilizing GAAP as a baseline but anticipating that Congress would specify certain discrete deviations for tax accounting. ${ }^{150}$

Partial conformity is not wholly alien to U.S. accountants. It exists in the U.S. for inventory accounting. Under current tax rules, companies are allowed to value inventory under either a "first in, first out" (FIFO) approach, in which case the value of inventory tends to approximate current costs, or a "last-in, first-out" (LIFO) approach, in which case historic inventory values tend to persist. However, companies electing to use the LIFO approach for tax purposes are required to use the same approach to valuing inventories in preparing the accounts presented to investors. ${ }^{151}$ In a period of rising prices, LIFO inventory valuation results in less taxable income than FIFO valuation. ${ }^{152}$

${ }^{149}$ Scholarly articles proposing or supporting some form of increased book-tax conformity include Yin, supra note 10, Celia Whitaker, Bridging the Book-Tax Accounting Gap, 115 YALE L.J. 680 (2005), Desai, supra note 10, and Mitchell L. Engler, Corporate Tax Shelters and Narrowing the Book/Tax “GAAP,” 2001 COLUM. BUS. L. REV. 539. Calls for increased conformity in the popular press are common as well. See, e.g., Alan Murray, Narrowing Tax Gap Should Be Priority of Next Congress, WALL ST. J., Oct. 8, 2002, at A4. Articles criticizing or questioning increased conformity include Johnson, supra note 11, Terry Shevlin, Corporate Tax Shelters and Book-Tax Differences, 55 TAX L. REV. 427 (2002), Hanlon \& Shevlin, supra note 11, Michelle Hanlon et al, Evidence on the Possible Information Loss of Conforming Book Income and Tax Income (working paper, Jan. 2005). Other useful articles examining book-tax conformity include Wolfgang Schon, The David R. Tillinghast Lecture: The Odd Couple: A Common Future for Financial and Tax Accounting, 58 TAX L. REV. 111, 115-116 (2005); Desai, supra note 146.

${ }^{150}$ See Yin, supra note 10, at 224; Whitaker, supra note 149, at 721; Engler, supra note 149, at 559; Desai, supra note 10, at 21.

${ }^{151}$ See IRC \& 472(c).

152 In determining taxable income, businesses that buy and sell inventory first calculate gross profit as follows: Gross profit $=$ receipts - cost of goods sold $($ COGS). COGS $=$ value of opening inventory + inventory purchased - value of closing inventory. Compared with FIFO, LIFO results in reduced gross profit and taxable income during inflationary periods because LIFO results in a relatively lower closing inventory valuation and a relatively greater cost of goods sold. See IRC $\S \S 471,472$; Michael J. Graetz \& Deborah H. Schenk, FEDERAl InCOME TAXATION: PRinciples AND POLICIES 750$54\left(5^{\text {th }}\right.$ ed. 2005$)$. 
But LIFO valuation also results in reduced reported earnings in inflationary times. This is the natural check that book-tax conformity provides and explains why some firms "voluntarily" pay taxes that could be eliminated by adopting LIFO and reporting lower earnings for both purposes. ${ }^{153}$

Inventory accounting is an isolated example of book-tax conformity in the U.S. Book-tax conformity is much more common in countries that traditionally have relied less on public markets to provide corporate finance, such as Germany, France, and Japan. ${ }^{154}$ In these countries mandated conformity often allows for company choice along the lines of the U.S. LIFO/FIFO example. German companies, for example, may elect to accelerate depreciation for tax purposes only if the depreciation deductions are reflected equally in the financial accounts.

Of course, in one sense the current U.S. system could be thought of as a "partial" book-tax conformity system. The tax code does provide that "[t]axable income shall be computed under the method of accounting on the basis of which the taxpayer regularly computes his income in keeping his books." ${ }^{156}$ But the exceptions swallow the rule, and the courts have long acknowledged that taxpayers cannot rely on GAAP where contrary to tax rules and regulations. ${ }^{157}$

\section{B. Issues and Concerns with Book-Tax Conformity Proposals}

My principal aim in this Part is to call attention to several unrecognized or underappreciated problems with book-tax conformity that arise from the effects of accounting on managerial and corporate behavior. However, before addressing those issues in the next section, this section summarizes and expands upon a number of other concerns with increased conformity.

\section{Information Loss}

The primary aim of financial accounting is to provide relevant, reliable, consistent, and comparable financial information to the capital markets in order to ensure

153 See GRAETZ \& SCHENK, supra note 152, at 754. U.S. oil companies generally use LIFO inventory accounting. For these companies, LIFO provides advantages for both tax and earnings purposes. The profits of the oil majors are very sensitive to world oil prices. When crude oil prices rise, gasoline pump prices rise, as do the profits of the oil majors, inevitably leading to price gouging investigations and calls for the imposition of windfall profits taxes on the oil companies. The negative political costs of high reported earnings arising from oil price jumps almost certainly outweigh other contracting costs as well as the oil executives' general preferences for high reported earnings. By holding down both reported earnings and taxable income in a period of rising oil prices, LIFO is unambiguously positive for the oil majors. See David Reilly, Big Oil's Accounting Methods Fuel Criticism, WALL St. J., Aug. 8, 2006, at C1 (discussing effect of LIFO on recent taxable income of Exxon Mobil and other U.S. oil companies).

154 See Paul J. Rutteman, A Comparative View of Accounting Regulations, in THE SEC AND AcCounting: The FIRst 50 YeArs: 1984 ProceEdings of the ARTHur Young Professors' RoundTABLE 95, 99-105 (Robert H. Mundheim \& Noyes E. Leech eds., 1984)

${ }^{155}$ See id. at 100; Schon, supra note 149, at 115-116.

156 IRC $\S 446(a)$.

157 See Thor Power Tool Co., 439 U.S. 522 (1979). 
efficient allocation of resources, ${ }^{158}$ and a principal concern of accounting researchers is that book-tax conformity would lead to a loss of value-relevant information. ${ }^{159}$ Generally, financial accounting standards best fulfill their information-providing role when they produce results that mirror economic accounting results, e.g., when financial depreciation mirrors economic depreciation. Thus, it has been argued that requiring financial statements to be prepared on the basis of tax accounting rules, or even conforming somewhere in between current financial and tax accounting rules, would result in the loss of value-relevant information. ${ }^{160}$ Studies demonstrate that financial statements are indeed less relevant in countries in which tax rules influence financial accounting rules. ${ }^{161}$

However, research shows that tax and financial accounts contribute individually to the efficiency of the market. ${ }^{162}$ As a result, even if GAAP were accepted as the basis for both books, there would be a loss of information. ${ }^{163}$ To be sure, the loss would be greater if financial accounts were prepared on the basis of the tax rules, but the elimination of either set of books would be costly from an information perspective. ${ }^{164}$

\section{Control of Tax Policy}

Some commentators doubt that Congress would be willing to cede control over tax rules to the FASB. ${ }^{165}$ Full conformity based on GAAP would result in a change in tax law every time the FASB issued a new standard. Even partial conformity with a GAAP baseline would cede substantial control of tax policy to the FASB. Unless Congress had already enacted a specific exception for a particular item or transaction, a change in GAAP would result in a change in tax unless and until Congress acted to override the change for tax purposes. Other arrangements for sharing responsibility are feasible, but a GAAP baseline for tax assessment seriously conflicts with congressional control over tax policy. ${ }^{166}$

Of course, some commentators, following the lead of Stanley Surrey, would applaud a change that would make it more difficult for Congress to implement social or

${ }^{158}$ See Financial Accounting Standards Board, Facts about FASB, at www.FASB.org (providing FASB mission statement).

${ }^{159}$ See Hanlon et al, supra note 149, at 2; Hanlon \& Shevlin, supra note 11, at 5.

${ }^{160}$ See Hanlon \& Shevlin, supra note 11, at 5. While book-tax conformity could theoretically occur anywhere along the continuum between financial accounting standards and tax accounting rules, Hanlon and Shevlin assume that Congress would not be willing to cede control of tax rules to a private standard setting body and that conformity would likely occur at or near tax accounting. See id. at 18. But see Yin, supra note 10 (arguing for book-tax conformity with a financial accounting baseline and limited specific deviations for tax purposes); Whitaker, supra note 149 (same).

${ }^{161}$ See Hanlon \& Shevlin, supra note 11, at 23 (citing Ashiq Ali \& Lee-Seok Hwang, CountrySpecific Factors Related to Financial Reporting and the Value Relevance of Accounting Data, 38 J. ACCT. RES. 1 (2000)).

${ }^{162}$ See Hanlon et al, supra note 149, at 37.

${ }^{163}$ See id.

${ }^{164}$ See id. (estimating that if the accounts were conformed based on tax rules, the reduction in the explanatory power of the income measure would be on the order of $50 \%$, but arguing that even conformity at GAAP would result in the loss of incremental information provided by the taxable income measure).

${ }^{165}$ See Hanlon \& Shevlin, supra note 11, at 4, Shevlin, supra note 149, at 435.

${ }_{166}$ See Shevlin, supra note 149, at 434 (discussing options for shared responsibility between Congress and the FASB). 
economic policy via the tax code. ${ }^{167}$ But the idea of Congress abandoning tax incentives is probably unrealistic. One could argue that if Congress' principal concern was the revenue associated with the corporate tax, Congress could easily cede responsibility for tax accounting to the FASB and simply adjust the tax rates as necessary. However, if one believes that Congress is as or more concerned with economic intervention via the tax code, then the likelihood is that a GAAP baseline tax with specific exceptions would rapidly degenerate into something approaching the current tax code as Congress enacted various tax favors, incentives and penalties. It seems much more likely that tax rules would serve as the basis for any book-tax conformity proposal acceptable to Congress.

\section{Instability Generally}

Essentially for the reasons given above, Hanlon and Shevlin have argued that partial conformity is inherently unstable, particularly partial conformity based on a GAAP baseline. ${ }^{168}$ Once exceptions to a GAAP-based tax are allowed, they argue, special interest lobbying would lead to greater and greater discontinuities. Full conformity may be unrealistic, but if achieved it could possibly be maintained. It is difficult to imagine a GAAP-based tax with a handful of specific tax exceptions not becoming two essentially separate systems.

\section{Politicization of the Financial Accounting Standard Setting Process}

Compared with the tax writing process, financial accounting standard setting seems blissfully non-political. Of course, business people lobby the FASB, ${ }^{169}$ and Congress and the SEC exert their influence from time to time, ${ }^{170}$ but by maintaining its emphasis on neutral rules of accounting, the FASB has deflected a great deal of potential interference. Increased book-tax conformity would almost inevitably lead to the politicization of financial accounting. ${ }^{171}$

Consider the scenario in which current tax rules or some hybrid between current tax and accounting rules enacted by Congress form the basis for both sets of books. Financial accounting would become just as much a political football as taxes are today, and lobbying would increase for the following reasons: First, public companies would have more at stake in the rules selected by Congress, since these rules would control for both tax and accounting purposes. Second, Congress's freedom to insert special interest accounting favors (or penalties) would increase given the shift from a single goal of promulgating neutral accounting standards to a multi-purpose, multi-policy tax and accounting standard setting process. Increasing the stakes in a venue that is more

167 See infra Part V.C.6 (discussing inefficiencies highlighted by Surrey in the provision of economic incentives through the tax code).

${ }^{168}$ See Hanlon \& Shevlin, supra note 11, at 18.

169 See, e.g., Lawrence D. Brown \& Ehsan H. Feroz, Does the FASB Listen to Corporations?, 19 J. BUS. FIN. \& ACCT. 715 (1992) (finding that the FASB is influenced by corporate comment letters and that larger corporations have more influence than smaller ones).

${ }_{170}$ See infra Part V.C.3.

171 See Shevlin, supra note 149, at 434-35 (noting inevitability of congressional involvement in standard setting with increased book-tax conformity). 
susceptible to lobbying would increase the expected payoffs from lobbying, and thus should result in more lobbying. ${ }^{172}$

On the other hand, suppose that a GAAP-based tax approach were adopted with specific tax deviations enacted by Congress. The FASB's influence over taxes would be significant in any mixed responsibility scenario. Despite FASB's neutrality stance, businesses could be expected to increase their lobbying of that organization, given the increased stakes involved in the FASB's pronouncements, and, since the odds of a congressional tax override would be uncertain, pressure on and by individual members of Congress to intervene in the FASB's deliberations would be intense. It may not be realistic to expect a private group of accountants to be able to navigate these political waters and successfully set both accounting rules and default tax rules. Even if it is feasible, this would not be an appropriate role for a private organization like the FASB. This realization provides further reason to think that conformity, if it is to occur, is more likely to happen at the tax end of the spectrum and fall firmly within congressional control. The primary point, however, is that any book-tax conformity proposal entails the politicization of financial accounting standard setting.

\section{Book-Tax Conformity and Corporate Behavior}

The costs of book-tax conformity described above are serious, but of course the benefits could be greater. This section, however, presents several additional concerns arising out of the effects of accounting results on managerial and corporate behavior that further undermine the case for book-tax conformity. In brief, the concerns are that increased book-tax conformity (1) is less likely to forestall artificial earnings inflation than most commentators assume, and indeed may result in excessive sacrifice of tax benefits for earnings; (2) will result in reduced consistency in financial reporting than exists today, making cross company comparisons more difficult; and (3) will undermine economic incentives whether conformity occurs at the tax end of the spectrum, the book end, or somewhere in between.

\section{Accounting and Operational Flexibility and the Book-Tax Tradeoff}

Because of the forced tradeoff between high reported earnings and happy investors on the one hand, and low taxable earnings and low corporate taxes on the other, book-tax conformity has been suggested as a response both to tax sheltering and artificial earnings inflation, depending on the dominant concern at the time. Fair enough, but is book-tax conformity more likely to reduce sheltering or inflated earnings? Where would

172 According to the economic theory of regulation, the benefits and burdens that are granted or imposed by the state on firms are subject to the laws of supply and demand, and lobbying expenditures are determined like any other business expenditure. Managers compare the expected payoffs from lobbying against other profit-seeking opportunities in optimizing the allocation of corporate resources. Under this model, the stakes and susceptibility of the regulator to being influenced are important determinants of lobbying effort and expenditure. See George J. Stigler, The Theory of Economic Regulation, 2 BELL. J. ECON. \& MGMT. SCI., 3 (1971) (the seminal article); see also, FrEd S. MCCHESNEY, MONEY FOR NOTHING: Politicians, RENT EXTRACTION, AND POLITICAL EXTORTION 1-19 (1997) (providing overview of the economic theory of regulation and focusing on the burden side of the equation, i.e., on the power of government to extort wealth from industry under the threat of adverse regulation). 
firms come out on the continuum between tax minimization and earnings maximization? As long as there is some managerial discretion over accounting choice and operational decisions, it would be impossible for a regulator to tie corporations to a point along that continuum.

Most commentators who have addressed this issue have suggested that tax minimization would dominate. ${ }^{173}$ The analysis developed herein suggests otherwise. It seems likely that book-tax conformity would result in managers sacrificing tax benefits for earnings to a greater extent than shareholders would prefer. Thus, increased book-tax conformity may be a partial answer to tax sheltering, but is unlikely to hinder artificial earnings inflation and indeed may result in some reduction in share values as managers act to maximize their own utility rather than that of shareholders.

\section{a. Flexibility in Managing Taxes and Earnings}

Whether conformity is achieved based on GAAP, the tax code, or something in between, managers would retain flexibility to manage taxes and earnings. Current GAAP is much more flexible than the tax code, and a certain degree of financial accounting flexibility is generally viewed as a positive feature. As discussed above, there are many users of financial data, and the flexibility in GAAP allows firms to choose the accounting treatments that most efficiently portray data and minimize contracting costs. ${ }^{174}$ But given the flexibility of GAAP, assessing corporate tax on reported income would provide companies with broad discretion to minimize tax or maximize reported earnings with respect to such key inputs as recognition of revenues and costs, inventory valuation, and depreciation. $^{175}$

A book-tax conformity approach utilizing a GAAP baseline with specific tax departures could provide either more or less flexibility than a straight GAAP-based tax, depending on whether the departures were mandated or made optional. In all likelihood, the result would be some of both. One can imagine Congress providing optional tax incentives for items such as depreciation and mandatory tax penalties for items such as non-performance based executive compensation. ${ }^{176}$

The current tax code provides less flexibility than GAAP, but some discretion does exist. For example, accelerated tax depreciation is not mandatory; firms can elect to apply straight-line tax depreciation. ${ }^{177}$ Firms may elect to deduct certain research and experimental expenditures instead of capitalizing them, but they are not forced to. ${ }^{178}$

Of course, even if accounting rules were fixed, accounting discretion would remain to the extent of operational discretion. For example, many companies have

${ }^{173}$ See infra notes $180-183$ and accompanying text.

${ }^{174}$ See supra note 62 and accompanying text.

175 See Jamie Pratt, Financial Accounting IN An ECONOMic Context 84-89, 279-286, 368$373\left(6^{\text {th }}\right.$ ed. 2006) (explaining accounting rules and choices relating to revenue and expense recognition, inventory valuation, and depreciation, respectively).

${ }^{176}$ These approaches would be consistent with the current tax code. As discussed below, accelerated tax depreciation is optional under IRC $\S 168(\mathrm{~b})$. On the other hand, the tax code contains mandatory tax penalties related to excessive provision of non-performance based executive compensation (IRC $\S 162(\mathrm{~m})$ ) and excess golden parachute payments (IRC $\S 280 \mathrm{G}$ ).

${ }^{177}$ IRC $\S 168(b)(3)(D)$.

${ }^{178}$ IRC $\S 174$. 
significant flexibility in managing accruals at year end. ${ }^{179}$ Under any of these approaches, operational flexibility would leave firms with choices between minimizing taxes and maximizing reported earnings.

\section{b. The Book/Tax Tradeoff}

How would firms exercise accounting and operational discretion in a book-tax conformity regime? Firm believers in the efficient capital markets hypothesis suggest that the primary result would be reduced reported income. Calvin Johnson has argued that companies would find other ways to communicate information to investors and would manage their books solely with an eye to minimizing taxes. ${ }^{180}$ Michelle Hanlon and Terry Shevlin have suggested that book-tax conformity could lead to a race to the bottom on effective tax rates. ${ }^{181}$ Peter Joos and Mark Lang have argued that book-tax conformity in Germany and France "has provided incentives to reduce taxes by reporting lower profits." 182

Other commentators are less convinced, pointing out the moderating effect of management's motivation to report high earnings. ${ }^{183}$ The lessons of this Article go further: Increased book-tax conformity would likely lead to increased instances of managers sacrificing legitimate tax benefits in order to boost reported earnings.

At the very least, the tax/earnings tradeoff literature provides strong evidence that increased book-tax conformity that leaves discretion with managers to choose between high earnings/high tax and low earnings/low tax treatments would not result in tax minimization. And positive accounting theory indicates that, to some extent, sacrificing taxes could be in the shareholders' interest. A tax minimization position would result in lower reported earnings that would increase the expected cost of debt covenant violation. At least for some firms, the potential costs of financial distress would outweigh the tax savings associated with reporting the lowest possible levels of tax and financial income.

However, given the direct and indirect effect of reported earnings on their compensation and other factors, managerial decision makers are likely to sacrifice taxes for earnings to a greater extent than necessary to maximize share value. Book-tax conformity is likely to reduce tax sheltering, but there is nothing to force managers to balance taxes against earnings in the shareholders' interests. The tax/earnings balance struck by management is likely to result in share value reductions and represents an underappreciated cost of increased book-tax conformity. ${ }^{184}$

${ }^{179}$ See, e.g., Paul K. Chaney \& Craig M. Lewis, Earnings Management and Firm Valuation Under Asymmetric Information, 1 J. CORP. FIN. 319, 319-320 (citing studies and relating anecdotal evidence of accrual management).

${ }^{180}$ See Johnson, supra note 11, at 427.

${ }^{181}$ See Hanlon \& Shevlin, supra note 11, at 28.

182 See Peter Joos \& Mark Lang, The Effects of Accounting Diversity: Evidence from the European Union, 32 J. ACCT. RES. 141, 145 (1994).

${ }^{183}$ See Schon, supra note 149 , at 143.

${ }^{184}$ The cost to shareholders of share value-reducing tradeoffs of tax benefits for earnings is obvious. The social cost may be less obvious. After all, as Vic Fleischer has suggested to me, this isn't a case of managers consuming excessive perks; they are paying excessive taxes to the government. But there is a social cost. Share value-reducing actions by managers result in reduced incentives to invest in equity securities and ultimately in reduced capital formation. Cf. CLARK, supra note 142, at 274 (making a similar argument that insider trading acts as a tax on investors which may chill capital formation). 


\section{Discretion and Cross Company Consistency in Financial Reporting}

While enhanced book-tax conformity would increase consistency between the books of a given firm, conformity could result in a decrease in the consistency and comparability of accounting results between companies in the same industry, assuming some flexibility in accounting treatment in a book-tax conformity regime. Assuming that the markets see through accounting presentation, decreased inter-company consistency is not necessarily fatal to book-tax conformity proposals, but it does represent an added cost. To some extent, analysts would have to work harder to produce comparable figures. ${ }^{185}$

Consider depreciation. Although businesses are permitted to employ one of a number of approved financial depreciation methods for various depreciable assets, the most common technique is straight-line depreciation, which simply prorates the cost of the asset, less estimated salvage value, over the estimated useful life of the asset. ${ }^{186}$ Straight-line financial depreciation is widely admired for its simplicity, but it is unlikely that this trait explains its dominance. After all, the same firms that utilize straight-line depreciation for financial reporting purposes utilize accelerated depreciation for tax purposes. Rather, straight-line depreciation is used for book purposes because, compared to the other permitted methods, it results in reduced depreciation expense and greater reported income in early years and increased expense and reduced reported income in later years. ${ }^{187}$ In other words, utilizing straight-line financial depreciation allows firms to maximize the present value of earnings reported to investors, while adopting accelerated depreciation methods for tax purposes allows firms to minimize the present value of taxes.

Imagine that corporate taxes were to be assessed on the basis of GAAP income. Firms would face a tradeoff between tax minimization and earnings maximization. Managers focused on tax minimization would adopt highly accelerated depreciation methods; those focused on earnings would select straight-line depreciation; some might compromise by selecting a modestly accelerated depreciation method. What factors would drive the choice? Positive accounting theory suggests that contracting costs would play a role, in which case firm size, degree of leverage, and the extent of earnings-based compensation arrangements would all matter. The previous section argued that management earnings preferences would be a key factor, and the strength of those preferences and the extent to which they would be satisfied would depend on executive

185 Although this section focuses on cross company consistency of financial reporting, cross company consistency of tax reporting is an important issue as well. Achieving conformity by assessing taxes on the basis of GAAP would result in increased company discretion and variability in taxable income and taxes, which could have an adverse effect on the perceived fairness of the tax system and taxpayer compliance generally. See Linda M. Beale, Book-Tax Conformity and the Corporate Tax Shelter Debate: Assessing the Proposed Section 475 Mark-to-Market Safe Harbor, 24 VA. TAX REV. 301, 370-80 (2004).

186 See DAVID R. Herwitz, Materials on ACCOUNTING FOR LAWYers 471 (1980); K. Fred SKOUSEN ET AL, FINANCIAL ACCOUNTING 354 (6 ${ }^{\text {th }}$ ed. 1996) (reporting a survey of 600 companies' annual reports finding that 558 employed straight-line depreciation, 50 employed the units-of-production method, and 106 employed accelerated methods. Obviously, a single company can employ different depreciation methods for different assets.)

187 See SKOUSEN ET AL, supra note 186, at 354. 
compensation design and other factors, including the quality of corporate governance. Given this multiplicity of factors, which may or may not be correlated among firms in a particular industry, accounting choices could vary widely even among firms in a single industry. Surely, they would vary more widely than they do today.

I do not wish to overemphasize this point, and I do not suggest that the cost resulting from greater inter-firm variation in accounting choices would be significant. A nuanced view of the ECMH recognizes that information gathering and assimilation is costly. Decreased inter-firm consistency in accounting choice would directionally increase analytical costs, but in all likelihood the impact on market efficiency would be minimal.

\section{Book-Tax Conformity and Economic Incentives}

We have already considered the effect of book-tax conformity on firm choices among acceptable accounting treatments and operational decisions with accounting implications, such as year-end accruals. This section considers a related but much more pervasive and important issue: How would book-tax conformity affect the explicit economic incentives Congress provides in the tax code and the implicit economic incentives embedded in GAAP? I argue that increased book-tax conformity would undermine economic incentives whether conformity is based on GAAP, on the tax code, on something in between, or left to company discretion.

\section{a. Tax Incentives}

As every student of basic federal income tax knows, the tax code is riddled with provisions that have little or nothing to do with "defining" income, i.e., determining the right level of income subject to tax in a platonic sense, and everything to do with providing incentives or subsidies to taxpayers. A familiar example is IRC $\S 106$ which generally excludes from the gross income of employees the value of employer provided health care and health insurance. Other in-kind benefits are included in an employee's income, so this exclusion represents a clear subsidy for the creation of employer funded health care plans.

Many of these tax incentives are directed at corporate behavior and at spurring business investment, including accelerated tax depreciation, ${ }^{188}$ "bonus" depreciation, ${ }^{189}$ investment tax credits, ${ }^{190}$ and special "expensing" provisions permitting immediate deduction of expenditures that otherwise must be capitalized and recovered through depreciation. ${ }^{191}$ The effect of each of these tax incentives is to increase the present value of deductions (and/or tax credits) associated with the expenditure and thus reduce the present value of taxes. By reducing the tax burden associated with qualified capital

${ }^{188}$ Taxpayers are allowed to take deductions for depreciation earlier and in greater amounts than "economic" depreciation would provide. Under IRC $\S 168$, the salvage values of assets are ignored, increasing the depreciable amount; the periods over which deductions are taken are shortened, often by as much as one-half of the assets' useful lives; and the depreciation methods generally are accelerated, with most assets being subject to $200 \%$ or $150 \%$ declining balance depreciation. See IRC $\S 168(\mathrm{~b}) \&$ (e).

${ }^{189}$ IRC $\S 168(k)$. See infra note 200 and accompanying text.

${ }_{190}$ See infra notes 193-194 and accompanying text.

${ }^{191}$ See infra notes 195-199 and accompanying text. 
expenditures, Congress expects businesses will devote more of their resources to or accelerate capital investment.

Full book-tax conformity utilizing a GAAP as a baseline would eliminate many of these tax incentives. ${ }^{192}$ Unless the tax incentives were replaced with direct subsidies or other non-tax incentives, we should expect some shift away from capital investment. Moreover, while some of the investment incentives are generic (accelerated depreciation applies to almost all depreciable assets and has been relatively stable over time), others are highly focused. For example, investment tax credits currently are available for alternative energy development ${ }^{193}$ and historic structure rehabilitation. ${ }^{194}$ Taxpayers may elect to deduct or capitalize periodical circulation expenses, ${ }^{195}$ certain research and experimental expenditures, ${ }^{196}$ soil and water conservation costs, ${ }^{197}$ environmental remediation costs, ${ }^{198}$ and certain other expenditures. ${ }^{199}$ In a bid to spur economic recovery in the wake of the $9 / 11$ terrorist attacks, Congress implemented a limited term, "bonus" depreciation provision allowing businesses to deduct immediately 30\% (later increased to $50 \%$ ) of otherwise depreciable capital expenditures. ${ }^{200}$ Although one can argue that these incentives could be more efficiently delivered by other means, the loss of these incentives is an argument against taxing corporate income on the basis of GAAP. More to the point, Congress is unlikely to relinquish the opportunity to intervene, whether its focused incentives reflect special interest lobbying or rational responses to market failures.

\section{b. Accounting Incentives}

One might be tempted to think that the economic incentive problem could be solved by conforming book and tax at the tax end of the spectrum, rather than the GAAP end, in other words, by reporting taxable income to both investors and the IRS. But that is not the case. As we have seen, accounting rules affect managerial behavior much as tax rules do, and adopting the Internal Revenue Code for financial accounting would eliminate many implicit accounting incentives.

Reconsider depreciation. As noted above, today most firms utilize straight-line financial depreciation for most items because the method is simple, but more importantly, because straight-line depreciation tends to maximize the present value of reported earnings. ${ }^{201}$ Because managers are motivated to report high earnings, the option to

${ }^{192}$ However, some tax incentives would remain. For example, although GAAP limits depreciation to cost minus salvage value, accelerated depreciation methods, such as the $200 \%$ declining balance method, are allowable.

${ }^{193}$ See IRC $\S 48$.

${ }^{194}$ See IRC $\$ 47$.

195 See IRC $§ 173$.

${ }^{196}$ See IRC $\S 174$.

${ }^{197}$ See IRC $\$ 175$.

198 See IRC $\$ 198$.

199 See e.g., IRC $\S 179$ A (qualified clean fuels vehicle credit).

200 The 30\% bonus depreciation allowance applied to certain property acquired after September 10, 2001 and before May 6, 2003. The allowance was later increased to $50 \%$ for property acquired after May 5, 2003, and placed in service before January 1, 2005. See IRC $\S 168(\mathrm{k})$.

${ }^{201}$ See supra note 187 and accompanying text. 
employ earnings enhancing straight-line depreciation (relative to accelerated depreciation) can be viewed as a financial accounting incentive for capital investment.

If firms were required to utilize the tax depreciation rules in preparing their financial reports, their appetite for capital investment would be lessened. Under the accelerated depreciation methods generally used for tax, the present value of reported expenses associated with capital investment would increase substantially, leading to deferral of capital investment or substitution away from capital investment and in favor of leasing or other non-capital operational alternatives at the margin. To be sure, the tax code permits firms to utilize straight-line depreciation, ${ }^{202}$ but even this election would not fully eliminate the earnings hit from the change in rules, given non-elective tax rules related to salvage value and depreciation periods that also accelerate deductions. ${ }^{203}$ Of course, any depreciation baseline is essentially arbitrary. There is no one correct depreciation technique that reproduces economic depreciation for all assets. But whether straight-line financial depreciation represents a subsidy or normality is unimportant, the point is that this and other gaps between GAAP and the tax code can be thought of as tax incentives, accounting incentives, or a mix of the two.

In many cases "GAAP incentives" are simply the flip-side of tax incentives. In other words, the financial accounting treatment may approximate economic reality, while the tax rules reflect subsidies. To some extent this is the case for depreciation. Another example is the disparate treatment of municipal bond interest. The interest on such bonds is not included in taxable income and generally is viewed as a subsidy to state and local governments that are able to reduce their borrowing costs through the issuance of these bonds. $^{204}$ But the interest received is included in reported earnings. ${ }^{205}$ Adopting a tax baseline for both tax and book purposes would preserve the tax incentive but introduce a financial accounting disincentive for corporations to purchase municipal bonds.

In other cases, GAAP permits income-increasing or income-accelerating accounting procedures relative to clearly more neutral treatments incorporated in the tax code. Examples include the failure to require expensing of compensatory stock options until this year and the recent elimination of the requirement to amortize purchased goodwill. ${ }^{206}$ Because these deviations resulted from industry lobbying, it is not surprising that they are income enhancing. What is surprising is that they have not been recognized as incentives, although they should be. Conforming GAAP with the arguably more neutral tax treatment of these items would tend to discourage the use of compensatory options and discourage merger activity.

The bottom line is that whether an accounting rule can be said to be neutral and economically correct and the corresponding tax rule to be the deviation and the incentive, or vice versa, it is important to mind the gap. Eliminating the gap in either direction will reduce the tax incentive, create an accounting disincentive, or do some of both.

${ }^{202}$ See IRC $\S 168(\mathrm{~b})(3)(\mathrm{D})$.

${ }^{203}$ See IRC $\S 168(\mathrm{~b})(4),(\mathrm{e})$.

${ }^{204}$ See IRC $\S 103$.

${ }^{205}$ See RoBert LibBy ET AL, FinANCIAL ACCOUNTING 514 ( $3^{\text {rd }}$ ed. 2001).

${ }^{206}$ Non-qualified stock options result in a tax deduction equal to the amount of income recognized by the optionee in the year of option exercise. See IRC $\S 83(\mathrm{~h})$. Under IRC $\S 197$ purchased goodwill is amortized ratably over a fifteen period. SFAS No. 142 provides that purchased goodwill need only be recognized for financial accounting purposes to the extent that it is impaired. 


\section{ACCOUNTING AND CORPORATE BEHAVIOR}

\section{c. Economic Consequences of Eliminating Accounting Incentives}

The theory and evidence suggest that the elimination of implicit accounting incentives in GAAP relative to the tax code would have economic effects comparable to the elimination of tax incentives as a result of adopting a GAAP-based tax. First, consider the effect of an earnings-decreasing change in accounting standards under the contracting cost theory, perhaps a shift from straight-line to accelerated depreciation. The debt covenant theory predicts that such a change would result in an indirect decrease in share prices. The markets would see through the accounting change in pricing company securities, but the reduction in reported earnings would make it more likely that firms would violate sticky debt covenants, increasing the expected cost of covenant violation. Reduced political costs might offset the debt covenant effect, as lowered reported earnings deflect the attention of congressional tax writers. In addition, sticky employment contracts that are based in part on reported earnings would tend to result in reduced compensation payments that might or might not be accompanied by reduced productivity. If debt covenant effects dominate, as suggested by the positive accounting theory literature, one would expect a net reduction in share prices resulting from an earnings-decreasing change in accounting standards. Thus, a shareholder-loyal manager would tend to make operational choices, including reduced capital investment, reflecting the earnings-decreasing change in accounting.

Once again, however, managerial appetite for earnings may exceed that of shareholders. Even if the negative effect of an earnings-decreasing standard change on stock prices is modest, managers may strongly resist the change and adjust operations to avoid it for self-serving reasons. As noted above, managers may honestly, but incorrectly believe that reduced reported earnings directly reduce share prices, they may be socialized into placing inordinate emphasis on high reported earnings, or they may simply react to the negative effect of reduced reported earnings on their own compensation.

We have already reviewed a great deal of empirical evidence suggesting that managers respond to financial accounting effects. I do not wish to rehash that evidence here, but we should consider what this evidence tells us about the potential impact of an earnings-decreasing change in accounting standards, such as a shift to the more accelerated depreciation rules of the tax code. There are several reasons to be cautious of reading too much into the empirical record. First, cases like Kamin concerning very large, one-time earnings hits, do not provide convincing evidence that managers take reported earnings into account in making day to day operational or investment decisions. Second, while the evidence indicating that stock option use has been largely accounting driven supports instrumental accounting, managers, as we have discussed, have a particular reason for wanting to keep their own compensation as obscure as possible, making it hard to generalize from that example. Perhaps the most persuasive evidence supporting significant behavioral responses to accounting standards lies in corporate reaction to earlier standard changes such as SFAS 106, which replaced pay-as-you-go accounting for post-retirement health care benefits with accrual accounting, and SFAS 13, which moved capital lease disclosures out of the footnotes and onto balance sheets. In both cases companies responded by making operational changes as if the reduced 
reported earnings mattered. In one case, managers slashed benefits; in the other they shifted away from capital leases towards more accounting-friendly operating leases. ${ }^{207}$

Overall, the theory and evidence suggests that accounting matters and that managers would respond to earnings-decreasing shifts in GAAP in a predictable fashion. However, one might assume that the economic effect would be transitory if contracting costs are an important part of the story. Once old debt agreements expire and new contracts are written taking into account tax code-based accounting standards, would the accounting disincentives disappear? In fact, they would not. Imagine that initially all companies employ straight-line financial depreciation. Next, Congress requires that financial depreciation be calculated under the more accelerated tax depreciation rules. The change has the effect of increasing the present value of expenses and decreasing the present value of earnings associated with capital investment. Under the debt covenant hypothesis, the share value of capital intensive companies would fall and firms would reduce or defer capital investment at the margin. Ultimately, corporate borrowers and lenders would respond to the new accounting environment by negotiating covenants associated with new bond offerings in which the level of earnings that triggers default is lowered. So equilibrium between corporate borrowers and lenders is restored. But that does not mean that the accounting bias against capital investment is eliminated. It persists. If a company were to ramp back up its capital expenditures, it would suffer a decrease in the present value of reported earnings, increasing the expected cost of default.

\section{Economic Consequences and Flexible Book-Tax Conformity}

The foregoing analysis suggests that reduction of the gap between tax and financial accounting would have adverse economic consequences however the gap is reduced. But it also suggests that if full conformity is the objective, how it is achieved matters. Allowing firms to choose the basis for conformity could minimize the adverse economic consequences. On the other hand, given flexibility, managers would be expected to make the earnings/tax tradeoff that maximizes their own utility, rather than shareholder value. On balance, it is unclear whether providing flexibility in book-tax conformity would benefit shareholders or not.

Individual company flexibility in achieving book-tax conformity is common. As we have seen, the one example of book-tax conformity currently in place in the U.S. requires consistency between LIFO and FIFO accounting for book and tax reporting, but leaves the choice up to individual companies. ${ }^{208}$ Similarly, German rules allow firms to choose between straight-line and accelerated depreciation, as long as they are consistent. $^{209}$ Moreover, these choices need not be binary. One can imagine permitting firms to select from a range of depreciation methods as long as internal consistency is maintained.

Shareholder-loyal managers could use such flexibility to minimize the adverse economic consequences of book-tax conformity. Firms that were relatively insensitive to reported earnings (because non-public or flush with cash) would select the conforming

207 The tax-earnings trade off literature discussed supra Part II.D reinforces the power of accounting results to shape corporate behavior.

${ }^{208}$ See supra note 151 and accompanying text.

209 See supra note 155 and accompanying text. 
treatment that minimized taxes, such as accelerated depreciation. Firms that were relatively insensitive to taxes (because of large net operating losses) would select the conforming treatment that maximized earnings. Firms in between these extremes would trade off earnings maximization against tax minimization.

Well governed firms would make these trade offs with an eye towards maximizing share value. The concern, of course, is that managers of many firms would sacrifice taxes for earnings to a greater extent than necessary to optimize share value. Of course, even if conforming treatments are specified by Congress, many managers would utilize operational flexibility in the same way. However, adding flexibility in accounting treatments is likely to exacerbate the agency problem.

\section{Further Book-Tax Conformity Alternatives and Alternatives to Conformity}

Full book-tax conformity is problematic from an economic consequences perspective. Better from this standpoint are partial book-tax conformity proposals, such as the idea of utilizing a GAAP baseline with specific tax deviations adopted by Congress. For example, Mitchell Engler has proposed a more nuanced approach to booktax conformity that would maintain intended tax incentives, such as accelerated depreciation, while closing pernicious gaps. ${ }^{210}$ Maintaining the disparate treatment of depreciation for tax and book purposes would maintain current tax and accounting incentives. Further, compared to the German flexible depreciation model, this proposal would limit the extent to which managers would inappropriately sacrifice taxes for reported earnings. The problem, of course, is identifying the pernicious gaps. Almost all deviations between GAAP and the tax code result in tax and/or accounting incentives. And, of course, as Hanlon and Shevlin have argued, the stability of partial book-tax conformity is open to question.

Although at first blush increased book-tax conformity seems an attractive approach to combating tax sheltering and artificial earnings inflation, commentators have pointed out numerous problems with proposals for enhanced conformity. The adverse economic consequences of increasing book-tax conformity, whatever the method, add to the arguments against adopting this tool and in favor of other means of attacking these problems, principally enhanced disclosure and reconciliation of book-tax differences. ${ }^{211}$ Detailed consideration of the merits of these alternatives is beyond the scope of this Article, but it is worth noting that unlike increased book-tax conformity, enhanced disclosure and reconciliation would add to the information available to the market and would have little or no economic consequence. Like footnotes to accounting statements, the tax reconciliation reports would have no affect on reported earnings or taxes paid. Of course, mandating more extensive reconciliations would increase rather than decrease compliance costs, but given the adverse economic consequences of book-tax conformity and other drawbacks, disclosure and reconciliation may be the superior approach.

\section{INSTRUMENTAL ACCOUNTING}

${ }^{210}$ See Engler, supra note 149.

211 See, e.g., Mills \& Plesko, supra note 145 (proposing revisions to the tax schedules used to reconcile tax and book income). 
This final Part considers a series of related policy questions that are prompted by recognition of the economic consequences of accounting standards, as outlined in the previous Parts: If earnings-decreasing shifts in GAAP made to increase book-tax conformity would have adverse economic consequences, would earnings-increasing adjustments to GAAP have positive economic consequences? Book-tax conformity aside, should we consider the economic consequences of accounting in the standard setting process? More affirmatively, should accounting standards be used instrumentally as a means of encouraging investment or otherwise shaping corporate behavior, an alternative to tax incentives, direct subsidies and legal mandates?

Of course, there would be drawbacks to adopting accounting standards that deviate from economic accounting, but in a second best world, they might serve as a valuable addition to the public policy toolbox. As we will see, replacing tax incentives or direct subsidies with accounting incentives could reduce the burden on the public fisc. However, the costs would be significant as well. Embracing instrumental accounting would open up the standard setting process to lobbying and potential capture by the interest group with the most at stake - corporate management. In addition, purposeful deviation from economic accounting would diminish the usefulness of accounting reports to investors and other users. This final Part briefly considers the potential benefits and costs of instrumental accounting. Although an omniscient and benevolent power could increase social welfare though the use of explicit accounting incentives, Congress is not such a power, and this Part tentatively concludes that social welfare is probably maximized by minimizing Congress' role in accounting and leaving the FASB to achieve as well as it can "neutral" standards of accounting.

\section{A. How Would Instrumental Accounting Work?}

Instrumental accounting would entail designing substantive financial accounting standards with a view towards shaping managerial, and thus corporate, behavior. Analogous to tax incentives and penalties, accounting incentives and penalties would represent purposeful deviations from ideal or "economic" accounting standards, i.e., standards that result in income figures that most closely approximate real world results. Historically, the FASB has rejected deviations from economic accounting for the purpose of providing incentives. ${ }^{212}$ This is not to say, however, that current accounting standards always match economic accounting. Achievement of ideal accounting standards is limited by at least two factors. First, the fundamental principal of conservatism results in a bias in favor of early recognition of expense and deferred recognition of income versus economic accounting. ${ }^{213}$ Second, ideal accounting would be prohibitively costly. Given the almost infinite variety of circumstances encountered by businesses, some simplifying rules of recognition must be employed to make the system operable. ${ }^{214}$ Within these constraints, however, the FASB has sought to approximate economic accounting.

${ }^{212}$ See Facts about FASB, supra note 155, at 2 (mission statement).

213 See Ross L. Watts, Conservatism in Accounting: Part I: Explanation and Implications, 17 ACCT. HORIZONS 207 (2003) (examining alternative explanations for and implications of conservatism in accounting, which at the extreme is defined by the adage "anticipate no profit, but anticipate all losses").

${ }^{214}$ Consider depreciation expense. Economic depreciation would reflect the estimated reduction in value of a depreciable item year by year and would be highly idiosyncratic. Because the cost of determining and maintaining hundreds or thousands of separate depreciation schedules for the various 
However, the potential for financial depreciation incentives is plain. As an example, let us again return to depreciation. As noted in the previous Part, shifting from straight-line to accelerated financial depreciation would result in reduced present value of reported earnings, thereby discouraging capital investment. Suppose, however, that Congress were to direct the SEC to permit decelerated financial depreciation for a certain class of assets. ${ }^{215}$ Businesses purchasing these assets could adopt a depreciation schedule that would result in even greater reported income in early years (because of smaller deductions in early years), with offsetting reductions in income in later years, compared against straight-line depreciation. Given all of the incentives discussed in previous Parts for managers to increase the present value of reported earnings, the option to adopt decelerated financial depreciation would spur investment in this class of assets.

The recent treatment of employee stock options suggests an even more direct means of providing accounting incentives - permitting companies to simply "footnote" the relevant expense rather than reducing reported earnings. Suppose, for example, that Congress wishes to spur corporate charitable contributions. These contributions are deductible for corporate tax purposes, ${ }^{216}$ but many corporations pay little or no tax due to losses incurred in previous years, other tax incentives that they have embraced, and, in some cases, questionable tax shelters. ${ }^{217}$ Moreover, the tax deduction will only go so far in spurring contributions by even tax paying businesses. Thus, Congress might decide that further incentives are in order. Suppose that Congress were to permit companies to refrain from "expensing" qualifying contributions, as long as the contributions were fully disclosed in a footnote to the financial statements, just as stock option expense was footnoted between 1995 and 2005. The result, of course, would be that charitable contributions would be free from an accounting perspective, and much more attractive to managers. Obviously, this footnoting technique could be used with virtually any current corporate expense that Congress wished to encourage, such as the cost of employer provided health care (either in place of or in addition to the current tax incentive), qualified pension contributions, etc.

\section{B. Benefits of Instrumental Accounting}

The primary benefit of providing corporate incentives through financial accounting rules would be the lack of cost to the public fisc. Replacing tax incentives or direct subsidies with accounting incentives would allow Congress to fund other programs, reduce tax rates, or pay down debt. Alternatively, accounting incentives could

vehicles, pieces of equipment, and structures owned by a business would be prohibitive, financial accounting standards provide for a limited menu of depreciation schedules.

215 Decelerated, or sinking fund, depreciation involves relatively small depreciation deductions initially that increase over the useful life of the asset. Decelerated depreciation matches economic depreciation for assets that suffer an increasing annual decline in value over their useful lives.

${ }^{216}$ See IRC $\S \S 170$ (a) \& (b)(2) (authorizing deductions for corporate charitable contributions but limiting the amount deductible to $10 \%$ of a corporation's taxable income).

217 See U.S. GENERAL ACCOUNTING OFFICE, COMPARISON OF THE REPORTED TAX Liabilities OF FOREIGN- AND US-CONTROLLED CORPORATIONS, 1996-2000 9 (2004) (63\% of U.S. corporations (excluding foreign-controlled corporations) and $45.3 \%$ of large U.S. controlled corporations (defined as those with at least $\$ 250$ million in assets or $\$ 50$ million in gross receipts) reported no federal income tax liability for the year 2000). 
be adopted in addition to existing non-accounting incentives, providing more total incentives without increasing taxes, and potentially filling gaps in the reach of current incentive programs. I am not suggesting that accounting incentives represent a free lunch. As discussed in the next sections, there would be significant costs associated with increased lobbying, potential regulatory capture, increased complexity, and diminished financial statement value. However, the fiscal effects of instrumental accounting would be positive.

As Stanley Surrey pointed out, direct governmental subsidies and tax incentives have an equivalent impact on the public fisc. ${ }^{218}$ Suppose Congress were to replace a tax incentive, such as accelerated tax depreciation, with a direct subsidy that returns the same aggregate dollars to the eligible businesses. This change would have no overall effect on tax rates because the additional tax revenues raised by eliminating the tax incentive would be needed to fund the direct subsidy. On the other hand, replacing either a tax incentive or a direct subsidy with an accounting incentive reduces the burden on the public fisc.

Each year Congress's Joint Committee on Taxation (JCT) prepares a "tax expenditure budget" that estimates the economic benefits provided by various tax preferences and incentives as compared with "normal" taxation. ${ }^{219}$ Whether and how a normal tax baseline can be defined is subject to great debate, and no one suggests that the figures can be used to estimate the revenue effects of eliminating the tax incentives, since behavior would change. ${ }^{220}$ Nonetheless, the figures give us some idea of the magnitude of the benefits provided through the tax code. The JCT's estimate for corporate tax expenditures for 2005 was $\$ 86$ billion. $^{221} 24 \%$ of that total, $\$ 21$ billion, was attributable to accelerated tax depreciation and provisions allowing otherwise depreciable items to be deducted immediately. ${ }^{22}$ Decelerating tax depreciation, while at the same time providing an earnings break for depreciation, could have a significant impact on the fisc while maintaining investment incentives.

Corporate sensitivity to accounting incentives would vary significantly depending on company leverage, size, and managerial sensitivity to reported earnings. But, of course, this is also true of tax incentives, and a mix of tax and accounting incentives potentially could be optimal. Firms that are flush with cash and profits may be relatively insensitive to reported earnings but quite sensitive to tax incentives; while firms that are unprofitable and nearing financial distress may be relatively insensitive to tax incentives but highly sensitive to earnings-increasing accounting choices. ${ }^{223}$

\section{The Costs of Instrumental Accounting}

${ }^{218}$ See Stanley S. Surrey, Tax Incentives as a Device for Implementing Government Policy: A Comparison with Direct Government Expenditures, 83 HARV. L. REV. 705, 726 (1970).

${ }^{219}$ See JOINT COMMITTEE ON TAXATION, ESTIMATES OF FEDERAL TAX EXPENDITURES FOR FISCAL YEARS 2005-2009, Jan. 12, 2005.

${ }^{220}$ See GRAETZ \& SCHENK, supra note 152 , at 46-56.

${ }^{221}$ See JOINT COMMITTEE ON TAXATION, supra note 219 , at 30-40.

${ }^{222} \mathrm{See} i d$. at 33. In determining the level of tax expenditure associated with accelerated depreciation and "bonus" expensing, the JCT uses a straight-line depreciation baseline. See id. at 6.

${ }^{223}$ As discussed supra note 217 , a majority of U.S. controlled corporations reported no tax liability for 2000. However, because corporate tax losses can be carried forward and back in time, a company reporting no tax liability for a particular year is not necessarily insensitive to tax incentives. See IRC $\S 172$. 
Embracing explicit accounting incentives as a regular tool of public policy would result in numerous dislocations and costs. First, although positive accounting theorists focus on contracting costs from an issuer's perspective, there are other parties to these contracts. Earnings-increasing changes in standards would result in some shifting of wealth from creditors to debtors. Second, instrumental use of accounting standards necessitates accepting deviations from accounting rules that most closely reflect the economic reality of various transactions. Such deviations entail costs arising from degradation of the information content of financial statements. Third, shifting the venue of some governmental economic intervention to the accounting arena would result in a shift and perhaps an increase in lobbying activity, and we might worry whether the standard setting process would be particularly susceptible to regulatory capture. Fourth, incorporating explicit accounting incentives into U.S. GAAP could undermine international convergence of accounting standards. Finally, there are a number of inefficiencies associated with providing incentives through the tax code, such as misplaced administrative responsibility, that might also apply to accounting incentives.

\section{Impact on Corporate Creditors}

Under the debt covenant theory, an accounting standard change that increases/decreases reported earnings, loosens/tightens sticky covenants, leading to an indirect increase/decrease in the share price of leveraged firms affected by the accounting change. Of course, there is another party to these debt covenants, the lender, and to some extent the shareholders' gains or losses are offset by losses or gains to the lender. Imagine an accounting standard change that decreases reported earnings, pushing a corporation closer to violation of its debt covenants and costly default. Clearly this is costly for the firm, but the lender may benefit. Companies may take other steps that reduce the risk of default that they would not otherwise have taken. In other words, companies may reduce the risk of actual default in order to offset the increased risk of technical default arising from the change in standards, and that benefits the lender. Positive accounting theory suggests that there will be an overall economic loss in this situation. Presumably, the corporate borrower and lender negotiated the ideal debt covenant based on previous accounting standards and the change in standard results in a suboptimal outcome. Nonetheless, the net economic loss is likely to be less than the loss to the shareholders.

By the same token, an earnings-increasing change in accounting standards pushes debtor corporations further from the brink of insolvency, reducing the expected cost of technical default, but because the standard change has no affect on the risk of actual default, the change undermines the protection afforded by the debt covenants, which is costly to lenders. Again, this is unlikely to be a "zero-sum" effect assuming, reasonably, that renegotiation of the covenants is not costless. The point, however, is that there is no free lunch. The benefit to debtors from earnings-increasing standard changes is costly to lenders.

However, the cost of earnings-increasing accounting changes for lenders is limited and probably would become even more limited if Congress were to embrace instrumental accounting. First, only existing debt agreements are affected by a change in 
accounting standards. New agreements can be as easily tuned to standard $B$ as to standard $A$. Second, although debt covenants generally are tied to "floating GAAP" today, meaning GAAP in force at the time of measurement, covenants could easily be tied to "frozen GAAP," the rules in force when the debt covenant is signed. Shifting to frozen GAAP also would entail costs, or presumably debt agreements already would be written in this fashion, but in an environment in which it was expected that Congress would regularly revise accounting standards to provide incentives, frozen GAAP agreements might turn out to be more efficient.

\section{Degradation of the Usefulness of Financial Reports}

There is an old debate in the academic accounting literature as to whether nonaccounting social welfare effects should be taken into account in setting standards. The accounting purists argued that these "economic consequences" of accounting standards should be ignored, that the rules should be as neutral as possible and avoid "influencing behavior in any particular direction." 224 The concern of the purists was that adjusting standards to reflect non-accounting consequences would lead to a loss of credibility and confidence in GAAP. ${ }^{225}$

Opposed were academics who believed that accounting neutrality was unattainable, ${ }^{226}$ that standard setters historically had taken non-accounting "economic consequences" into account in promulgating rules, ${ }^{227}$ and that it was the affirmative obligation of the standard setter to take these economic consequences into account. ${ }^{228}$ This debate has quieted in recent years, and it would appear that the purists won the aspirational battle, at least. Recent FASB statements uniformly embrace the economic neutrality objective. ${ }^{229}$ The only "economic consequence" recognized by FASB as having a legitimate role in standard setting is the economic benefits of changes "that result[] in financial statements that are more relevant and representationally faithful, and thus more useful for decision making.",230

Although unstated, presumably the central concern of the GAAP purists was that a loss of credibility or confidence in GAAP would be costly. If audited financial statements become less credible, reliable, or useful as a result of consequentialist changes in standards, users of these statements would be forced to seek alternative sources of data, negotiate more protective agreements, or simply accept greater risk in dealing with an issuer, all of which is costly.

224 Facts about FASB, supra note 155 (quote from mission statement). See also DAVID Solomons, MAKING ACCOUNTING POLICY 233-35 (1986) (arguing the importance of accounting neutrality); Victor H. Brown, Accounting Standards: Their Economic and Social Consequences, AccT. HORIZONS, Sept. 1990, at 95-96 (same).

${ }_{225}^{25}$ See Brown, supra note 224, at 94; SolOMONS, supra note 224, at 232.

226 See David M. Hawkins, Financial Accounting, the Standards Board and Economic Development, THE SAXE LECTURES IN ACCOUnTING, Nov. 12, 1973, at 4.

${ }^{227}$ See Stephen A. Zeff, The Rise of "Economic Consequences," J. ACCT., Dec. 1978, at 58.

228 See Hawkins, supra note 226, at 9.

${ }^{229}$ See Facts about FASB, supra note 155, at 2 (mission statement).

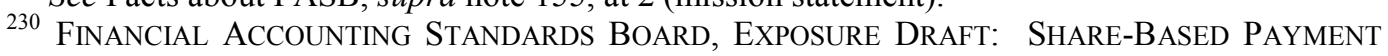
(Mar. 31, 2004), at C34. 
As highlighted by recent literature from the book-tax conformity debate, the more general worry is that departure from financial accounting neutrality would have adverse effects on value-relevance of financial statements. ${ }^{231}$ However, not all departures from existing financial accounting standards are equally problematic. As an example, Hanlon and Shevlin consider the effect on conforming depreciation techniques, specifically using the accelerated tax depreciation rules for financial reporting. In this case, they argue that the change would result in a "minimal" loss of information "because economic depreciation of an asset does not follow either [the tax or book depreciation method] exactly."232

More generally, deviating from neutrality in order to provide accounting incentives results in costly information loss to the markets only if information is truly lost. As long as the standards are unambiguous, shifting from straight-line financial depreciation to some explicit decelerated depreciation method, should have minimal informational impact. Even more clearly, shifting an expense from income statement to footnote should have no impact on information, just as shifting options expense from footnote to income statement will have no informational impact. ${ }^{233}$

Thus, while deviating from neutral accounting principals in order to provide incentives would inevitably result in some degradation in the value-relevance of financial statements, the impact could be limited by focusing on the presentation of information, i.e., shifting expenses to footnotes, and maintaining the overall substance of the information provided. ${ }^{234}$ Adverse impact could be limited further by being highly selective in adopting the instrumental accounting approach. For example, given the inherent difficulty of matching depreciation schedules to economic depreciation, the informational cost of adjusting financial depreciation schedules to spark investment might be modest. Overall, the impact of limited deviations that are carefully implemented to preserve as much value-relevant information as possible would likely be small.

\section{Lobbying, Regulatory Capture and the Quality of Accounting Incentives}

Given the fundamental economic policy issues at stake, instrumental accounting should be a tool utilized only by Congress, if at all. The FASB has quite correctly refused to consider economic consequences in its standard setting process. A private body of accountants is not equipped to weigh non-accounting issues and has no access to the other, competing means of economic intervention available to Congress. Thus, embracing instrumental accounting would entail relocating some responsibility for the standard setting process from the FASB to Congress. Primary responsibility could

${ }^{231}$ See id. at 2 (arguing that value relevance could be undermined "if standard setting and GAAP is captured by tax rule-makers, policy makers, and politicians").

${ }^{232}$ Hanlon \& Shevlin, supra note 13 , at 29.

${ }^{233}$ Keep in mind that there may be other costs or benefits associated with these adjustments, such as contracting cost effects, but the claim here is that these cosmetic changes need not result in degradation of information made available to the market.

${ }^{234}$ One might argue, and it could be true, that an earnings-increasing accounting incentive would be less effective if the only change was to shift an expense from the body of the financial statement into a footnote providing a pro forma earnings calculation undoing the change. However, this has been the situation with stock option expensing from the last decade, and that "incentive" has been very successful. 
remain with the FASB, with Congress intervening from time to time with respect to particular standards, or, following the tax model, primary responsibility could be shifted to Congress with implementation entrusted to a governmental agency or perhaps the FASB. In either scenario, however, we should expect increased lobbying over standards, worry about the potential for capture by managerial interests, and question the quality of instrumental standards that would be promulgated. While a benevolent, disinterested, and omniscient social planner could make positive use of instrumental accounting, the politics of standard setting should lead us to question whether adding instrumental accounting to the regulatory tool kit would increase or decrease social welfare.

There is certainly reason to be concerned about lobbying costs and regulatory capture if instrumental accounting were to become the norm. Corporate managers would have a very strong interest in lobbying Congress and whatever committees Congress empowered to oversee financial accounting for earnings-increasing standards, and it is not at all clear that there would be any effective lobbying interests countering them. ${ }^{235}$ Creditors would be hurt by earnings-increasing standards that undermined the protection of debt covenants, but dispersed bond holders, for example, should not be expected to form an effective lobby. Moreover, as discussed above, ${ }^{236}$ the rational move for creditors might be to negotiate covenants relying on frozen GAAP, rather than fighting management over accounting standards forming the basis for floating GAAP covenants. Shifting to frozen GAAP would not eliminate managers' lobbying incentive, but it would remove a potential, though weak, countervailing lobbying force. Finally, auditors and accountants certainly have an interest in accounting standards, but they are more likely to be concerned about the consistency and ease of administration of the rules than their substance.

Accounting commentators have worried that eliminating economic neutrality as a guiding principle of the standard setting process would lead to a lobbying frenzy and severely undermine principled standard setting. ${ }^{237}$ That is not to say that lobbying does not occur today or that it is totally ineffective. There is evidence that corporations effectively lobby the FASB. ${ }^{238}$ But casual observation suggests that corporate lobbying with respect to accounting standards does not approach lobbying of tax writers. Perhaps that is because managers care more about taxes than reported earnings, but I strongly doubt it. It is more likely that the difference arises from the belief that the FASB, with its

${ }^{235}$ See supra note 152 and accompanying text for a brief discussion of the determinants of lobbying effort and expenditure.

${ }^{236}$ See supra Part V.C.1.

237 See SolOMONS, supra note 225, at 114 (noting "general agreement among accountants that anything that can limit the area of political disagreement in accounting will be beneficial"); Hanlon et al, supra note 149, at 37 (suggesting that Congress as a political body would be more susceptible than FASB to lobbying); Financial Accounting Foundation Board of Trustees, News Release 06/14/04: Financial Accounting Foundation Trustees Issue Statement Opposing Legislative Proposals to Curb FASB Independence (accessible via FASB website) (voicing concern regarding "Congress send[ing] the message that special interests are able, through legislation, to overturn expert accounting judgment”).

238 See Brown \& Feroz, supra note 169 (finding that the FASB is influenced by corporate comment letters and that larger corporations have more influence than smaller ones). See also, Edward B. Deakin, Rational Economic Behavior and Lobbying on Accounting Issues: Evidence from the Oil and Gas Industry, 64 ACCT. REV. 137 (1989) (investigating lobbying on accounting for oil and gas producing activities and finding that contracting and cash flow effects were correlated with lobbying activity). 
focus on neutrality, rejection of non-accounting policy considerations, and insulation from the electoral process, is less susceptible to lobbying than Congress. ${ }^{239}$

Congress has rarely intervened in the standard setting process, but its occasional interventions give us some clues about the welfare implications of instrumental accounting. Two examples demonstrate the promise and the peril:

One of the most significant interventions by Congress and the SEC in substantive standards occurred in the early 1960s after Congress enacted an investment tax credit. Although the tax legislation provided for immediate "flow-through" tax benefits, the Accounting Principles Board (FASB's predecessor) issued an opinion requiring that the tax benefits be spread over the lives of the assets purchased for financial reporting purposes. ${ }^{240}$ This conservative approach reduced the favorable earnings impact of the tax legislation (versus a parallel flow-through financial accounting approach). The accounting profession was split on the proper treatment, but business leaders lobbied hard for flow-through accounting. ${ }^{241}$ The SEC took the unusual step of overturning the APB's opinion with its own opinion allowing either accounting method to be used. ${ }^{242}$ About a decade later, Congress enacted a new version of the investment tax credit and specified in the legislation that either accounting approach would be acceptable - a rare case of Congress engaging in instrumental accounting. ${ }^{243}$ In my view, these were positive interventions. By permitting flow-through accounting of the tax benefits, Congress and the SEC boosted the incentive provided by the investment tax credit with no additional cost to the fisc and little loss of information to the financial markets.

The other example involves only threatened intervention and takes us back to the stock option expensing story. As discussed above, the FASB struggled for a decade before successfully implementing a requirement that stock option expense be recognized consistent with other forms of compensation. Corporate interests strongly resisted this earnings-reducing change in standards and several times enlisted the help of various members of Congress in pressuring the FASB to slow or water down its proposals. To be fair, other members of Congress supported the FASB's efforts, but had the primary responsibility for this standard rested with Congress, I have no doubt that the corporate interests would have prevailed. Expensing stock options will discourage their use and the new standard can be seen as an unwarranted brake on a popular compensation technique. In my view, the old option expense footnoting regime provided an inappropriate accounting preference for one particular type of compensation, leading to inefficient distortions in pay practices, i.e., over-reliance on options, and a particular form of options at that. The problem, of course, is that this story is not about a difference of opinion

239 According to the economic theory of regulation, lobbying expenditure is a function of the potential payoff from lobbying. See supra note 152 and accompanying text. All else being equal, the expected return on lobbying a more compliant regulator is greater than the return on lobbying a less compliant regulator.

240 See Gary John Previts \& Dale L. Flesher, A Perspective on the New Deal and Financial Reporting: Andrew Barr and the Securities Exchange Commission, 1938-1972, 23 BuS. \& ECON. HIS. 221, 226 (1994); Joel Seligman, The SEC and Accounting: A Historical Perspective, in THE SEC AND ACCOUNTING: THE FIRST 50 YEARS: 1984 PROCEEDINGS OF THE ARTHUR Young ProfESSORS' RoundtaBle 3, 19 (Robert H. Mundheim \& Noyes E. Leech eds., 1984)

${ }^{241}$ See Seligman, supra note 240, at 19.

${ }^{242}$ See id.; Previts \& Flesher, supra note 240, at 226; David Solomons, The Political Implications of Accounting and Accounting Standard Setting, 13 ACCT. \& BUS. RES. 107, 117 (1983).

${ }^{243}$ See Previts \& Flesher, supra note 240, at 226. 
regarding the merits of stock options, it is about managerial interests that differ from shareholder interests and the likelihood that Congress will cater to management interests.

In my view, the problem of regulatory capture and the resulting likelihood that a Congress that embraced instrumental use of accounting standards would produce as many poor standards as good ones probably dooms the enterprise. Perhaps this is an unduly pessimistic view of Washington, but the view seems warranted. Of course, one can make the same point about tax incentives. The difference is that congressional involvement in the tax writing process is inevitable. That is not the case with the financial standard setting process, but more on that after we consider a few other potential costs and benefits of instrumental accounting.

\section{Institutionalization of the Importance of Reported Earnings}

The idea behind instrumental accounting is to harness managers' irrational or rational but self-serving bias, which inflates the importance of reported earnings, in order to shape corporate behavior and increase social welfare. There is an inherent perversity in this idea, in that shareholder welfare would be increased if managers could be educated or disciplined into abandoning the bias in the first place. One might be concerned that explicit introduction of accounting incentives into GAAP would somehow institutionalize managers' earnings fixation and lead us further from the happy day in which managers fully understand and internalize the ECMH and positive accounting theory.

\section{Conflict with International Convergence of Accounting Standards}

In 2002, the FASB and the International Accounting Standards Board entered into a memorandum of understanding pledging to work towards "high-quality, compatible accounting standards that could be used for both domestic and cross-border financial reporting." 244 Currently, there is no single set of accounting principles that is generally acceptable in all capital markets, and international convergence would result in obvious efficiencies.

Incorporating explicit accounting incentives into U.S. GAAP could undermine efforts to achieve international accounting convergence. For example, financial depreciation schedules that were regularly adjusted to fine-tune the incentives for U.S. companies to invest in certain asset classes would be problematic for convergence and add to the administrative burden of foreign firms attempting to list their shares on U.S. markets.

Without attempting to fully solve this problem here, a number of observations are in order. First, it would appear that the negative effect on international convergence could be minimized by limiting accounting incentives to a few discrete issues, such as financial depreciation, and by implementing the incentives in such a way as to avoid information loss, e.g., by employing the stock option "footnoting" technique. These are the same techniques that were suggested above as means of minimizing the loss of information in deviating from economic accounting, so introduction of the international convergence issue simply reinforces the reasons for cabining accounting incentives.

${ }^{244}$ See Memorandum of Understanding between FASB and IASB ("The Norwalk Agreement"), Oct. 2002, accessed via FASB website. 
Second, it should be noted that calls for increased book-tax conformity raise the same issue unless one believes that the systems would be conformed at economic accounting, which seems unlikely. In both cases, the reduction in international convergence is a cost of the proposal that must be weighed against the benefits.

\section{Other Costs (and Benefits) of Instrumental Accounting}

In a number of important articles and books Stanley Surrey and Paul McDaniel exposed the inefficiencies of providing business incentives through the tax system rather than through direct subsidies. ${ }^{245}$ Accounting incentives would share many, but not all, of these inefficiencies.

One of Surrey and McDaniel's primary complaints was that tax incentives bypass the Congressional committees and regulatory agencies that have the relevant subject matter expertise, e.g., agriculture, manufacturing, etc. ${ }^{246}$ Not only is there a loss of expertise when this occurs, but a loss of coordination. Assuming that Congress patterned accounting incentive institutions on the tax model, this complaint would be equally valid. Of course, this institutional framework is not inevitable. Congress could decide that the various subject matter committees could employ accounting incentives as a policy tool in coordination with direct subsidies and other incentives. This alternative approach could result in the opposite coordination problem, different committees imposing different or conflicting accounting standards. This is not the place to work out a detailed regulatory scheme for the promulgation of accounting incentives, but two points should be emphasized: coordination problems and loss of expertise might arise in the promulgation of accounting incentives, but the problems inherent in the tax model potentially could be mitigated.

Another complaint was that tax incentives were open ended. ${ }^{247}$ Unlike direct subsidies that must pass through an appropriations process every year, tax incentives, once enacted, remain until they are eliminated or revised by future legislation. Accounting incentives would be similarly open ended. Because accounting incentives have no direct impact on the public fisc, however, it is not clear that this is a significant problem. $^{248}$

A further concern was that tax incentives damage the tax system through introducing complexity and inconsistency. ${ }^{249}$ This risk would exist for accounting incentives as well. Ideally, Congress would impose just a few narrowly tailored accounting incentives that were designed to preserve relevant financial information while encouraging worthwhile economic behavior. But it is entirely possible that once the camel's nose breached the tent we would wind up with a volume of accounting standards

${ }^{245}$ See Surrey, supra note 218; StAnley S. SURREY, PATHWAYS TO TAX REFORM: THE CONCEPT of TAX EXPEnditures (1973); Stanley S. Surrey \& PAUl R. MCDANIEL, TAX EXPENDITURES (1985).

${ }^{246}$ See Surrey, supra note 218, at 728; SURREY \& MCDANIEL, supra note 245, at 106.

${ }^{247}$ See SURREY, supra note 245 , at 729-30 \& n. 34.

${ }^{248}$ For that matter, tax incentives are much less open ended than they used to be. Increasingly, tax incentive provisions are enacted for a limited period and must be affirmatively renewed to continue in force. See, e.g., IRC $\S 168(\mathrm{k})$ (titled, "Special [Depreciation] Allowance for Certain Property Acquired After September 10, 2001, and Before January 1, 2005”).

${ }^{249}$ See SURREY, supra note 245, at 731-32; SURREY \& MCDANIEL, supra note 245, at 105-06. 
that rivaled the tax code. This issue is sufficiently serious that it is discussed more fully in the next section.

Accounting incentives would be similar to tax incentives in other ways. Both mechanisms generally are very blunt tools for economic intervention. Consider the corporate deduction for charitable contributions. For firms paying tax at the top marginal rate, this deduction amounts to a $35 \%$ governmental subsidy for charitable gifts. Is it likely that Congress actually thinks that $35 \%$ is the right level of subsidy? Why not $25 \%$ or $50 \%$ ? And what about the startup firm with no net taxable income that has tax losses that can be carried forward for many years? The effective subsidy in that case rapidly approaches zero. Is that what Congress intended? In some cases, principally tax depreciation and investment tax credits, Congress has actively managed tax incentives. More often than not, however, they serve as a very blunt instrument.

Accounting incentives would suffer from the same defect. Decelerated financial depreciation could be fine tuned based on experience, but shifting an expense from income statement to footnote would have a dollar for dollar impact on reported earnings, whether this level of earnings impact would provide the right level of incentive or not.

On the other hand, tax and accounting incentives share an advantage with direct subsidies relative to legal mandates in allowing for heterogeneous responses. Assuming that Congress merely wants to encourage an activity and not require it, tax and accounting incentives as well as direct subsidies allow businesses to determine whether the carrot is sufficiently attractive to merit the change. However, all of these pros and cons are simply further factors to be taken into account in determining whether instrumental accounting is a viable tool for implementing government policy in a second best world.

\section{Thinking about Accounting Incentives in a Second Best World}

It may be useful to think about accounting incentives in the context of the tax simplification debate. The issues are similar. Undoubtedly, the tax system could be more efficiently administered if stripped of various economic incentives such as the home mortgage interest deduction, the deduction for charitable contributions, the earned income tax credit, and the exclusion for employer provided health insurance. But we live in a second best world. Assuming one believes that government has a legitimate role to play in shaping economic behavior (or even if one believes that government inevitably will play that role whether it is legitimate or not), the appropriate question is what combination of tax rules, legal mandates, governmental spending programs, and, perhaps, accounting standards, most efficiently raises the revenue, shapes the behavior, delivers the services, and provides the information. Congress only has so many levers it can use to direct economic behavior. None is cost free.

David Weisbach and Jacob Nussim have recently made this point with respect to tax incentives. As they say, "[t]he government will, sometimes for the better and sometimes for the worse, subsidize, penalize, or regulate various activities, and we must decide how this should be done." ${ }^{, 250}$ They argue that it is mistake to focus narrowly on the effect of a tax incentive on the complexity and efficiency of the tax code; rather one

${ }^{250}$ David A. Weisbach \& Jacob Nussim, The Integration of Tax and Spending Programs, 113 YALE L.J. 955, 964 (2004). 
must consider broader institutional design considerations in determining whether it is appropriate to deliver incentives through the tax code. ${ }^{251}$

A similar argument could be made for instrumental use of accounting. Accounting researchers bemoan potential degradation of financial information, but there is no reason to think that maximum value-relevance of financial statements should supersede all other considerations. But there is also a fundamental difference between accounting and tax. Congressional involvement in the federal tax system is unavoidable, and thus lobbying and regulatory capture problems in this arena are endemic. This is not true of financial accounting. With one or two exceptions, Congress historically has not involved itself with substantive accounting rules. We should, therefore, think twice before inviting the camel's nose into this particular tent. While one can dream of an allwise and wholly public-spirited Congress tweaking one or two accounting rules to provide helpful incentives to business, the nightmare scenario of one-off, special interest driven accounting rules looms large. As noted above, the constituency with the greatest interest in accounting standards and strongest incentive to lobby is corporate management. ${ }^{252}$ The concern, then, is not that inefficient governmental economic intervention would simply shift from tax incentives or direct subsidies to accounting incentives, but that opening up a new venue for intervention would result in incremental social costs, including increased lobbying and regulatory costs, that offset the fiscal and other advantages instrumental accounting would provide.

Still, given the power and economy of financial accounting standards, it is tempting to propose limited consideration of accounting incentives, perhaps as a tiebreaker in situations in which the proper accounting treatment of an item is subject to legitimate debate within the accounting profession or possibly with respect to items for which the accounting treatment is admittedly arbitrary to begin with. A good example of the former case was the resolution of the disagreement over the accounting treatment of the investment tax credit. But, of course, distinguishing legitimate debate from concocted accounting controversies designed to advance special interest would not be easy. I would place the debate over the FASB's proposal to require expensing of compensatory stock options in the latter category.

The best example of an arbitrary accounting standard is probably financial depreciation. The benefits of allowing firms to utilize more decelerated financial depreciation methods than are permissible today would seem to outweigh the costs. But, again, aspects of many standards could be deemed arbitrary, and limiting intervention to this subset of standards would not be easy.

If instrumental accounting could be limited to breaking ties in cases of legitimate accounting controversy or adjusting arbitrary standards to take the pressure off of tax incentives and direct subsidies, there could be significant social gains. I would welcome suggestions along these lines. However, without reason to think that intervention could be limited, the risks of encouraging intervention seem to outweigh the gains. And this brings us back to the book-tax conformity debate. While increased conformity may be advantageous in isolation, we should be concerned that encouraging Congress to intervene in financial accounting in the name of conformity could start us down the road towards wholesale politicization of the standard setting process.

\footnotetext{
${ }^{251}$ See id. at 958-60.

${ }^{252}$ See supra Part V.C.3.
} 


\section{CONCLUSION}

Using financial accounting standards to help shape corporate behavior is a provocative idea, but whether instrumental accounting ultimately is embraced as a public policy tool is to some degree secondary. The main argument of this Article has been that accounting standards shape corporate behavior, whether we recognize the fact or not, and that this power of accounting has important public policy implications. We cannot adequately evaluate calls for increased book-tax conformity or other proposals with accounting implications without taking the incentive properties of accounting rules into consideration.

Even more generally, it is regrettable that there is so little cross-fertilization of ideas between researchers focused on accounting and those specializing in law and corporate governance. Positive accounting theory may not be a complete explanation for why accounting matters, but it is an important theory with a rich empirical literature that corporate governance scholars must reckon with. On the other hand, accounting researchers would benefit from more thorough incorporation of agency theory into their models. Accounting is too important to be left to accountants, and much too important to be left to the unquestioned discretion of corporate managers. Further research building on the groundwork laid by several disciplines is needed to provide a fuller account of why and how accounting matters, what we can and should expect from managers faced with accounting and accounting-sensitive operational choices, and the proper policy role for financial accounting standards. 